\title{
Jesús F. Contreras, escultor finisecular. Entre la patria chica, el nacionalismo y el cosmopolitismo
}

\author{
Jesús F. Contreras, Sculptor. Between the \\ Homeland, Nationalism and Cosmopolitanism
}

\author{
Luciano Ramírez Hurtado \\ (D) 0000-0002-2302-2574 \\ Centro de Ciencias Sociales y Humanidades \\ Universidad Autónoma de Aguascalientes, México \\ lramirez@correo.uaa.mx
}

\section{Marco Antonio García Robles \\ (D) 0000-0001-7605-4556 \\ Universidad Autónoma de Aguascalientes, México \\ marcogarciarobles@gmail.com}

Resumen: Desde los estudios regionales, con base en el método biográfico que busca una nueva valoración sociocultural del artista, este trabajo describe y analiza una serie de aspectos hasta ahora desconocidos del escultor aguascalentense Jesús F. Contreras (1866-1902). Abrevando en fuentes documentales escasamente exploradas, así como en bibliografía clásica y de reciente producción sobre el personaje, además de hemerografía (prensa escrita publicada en Aguascalientes, ciudad de México y París a finales del siglo xix y principios del $\mathrm{xx}$ ) e imágenes fotográficas inéditas (procedentes del álbum fotográfico de la familia Contreras), el artículo propone una nueva visión desde lo local, sin perder de vista el contexto nacional e internacional, en un ir y venir entre el nacionalismo y el cosmopolitismo prevaleciente de la época. Su importancia radica en que abre nuevas vetas historiográficas y de investigación pues, entre otras cosas, da cuenta de su amplia red de relaciones familiares y de amistad. 
Palabras clave: Jesús F. Contreras; escultura; regionalismo; nacionalismo; cosmopolitismo.

Abstract: From regional studies, based on the biographical method that seeks a new sociocultural assessment of the artist, this article describes and analyzes a series of hitherto unknown aspects of the Aguascalientes sculptor Jesús F. Contreras (1866-1902). Examining rarely explored documentary sources, as well as classic and recent bibliography on this character, in addition to hemerography (the written press published in Aguascalientes, Mexico City and Paris at the end of the 19th century and beginning of the 20th century) and unpublished photographic images (from the photo album of the Contreras family), the article proposes a new vision from the local level, without losing sight of the national and international context, in the fluctuation between nationalism and the prevailing cosmopolitanism of the time. Its importance lies in the fact that it opens up new historiographic and research veins because, among other things, it explains its wide network of family relationships and friendship.

Key words: Jesús F. Contreras; sculpture; regionalism; nationalism; cosmopolitanism.

Fecha de recepción: 21 de agosto de 2017 Fecha de aceptación: 19 de diciembre de 2017

\section{INTRODUCCIÓN}

Tesús Fructuoso Contreras Chávez (Aguascalientes, Ags.-1866, México, D. F., 1902), adquiriría en su patria chica algunas bases de sus facultades artísticas, estudiaría en la Escuela Nacional de Bellas Artes (ENBA), de la ciudad de México, sería becado por el gobierno para estudiar en Francia, se convertiría en el escultor decimonónico finisecular mexicano más importante, haría una carrera profesional destacada, se encumbraría como un empresario exitoso gracias a su cercanía con el general Porfirio Díaz y ganaría prestigio por sus participaciones y reconocimientos en las exposiciones universales de París de 1889 y 1900, en un ir y venir entre el nacionalismo y el cosmopolitismo (Tenorio, 1998, pp. 81-239). Cabe subrayar que nunca perdió 
vínculos con su ciudad natal, a la que tanto quiso, donde tenía familia y entrañables amigos y cuya sociedad seguía con atención -a través de la prensasus pasos, dificultades y logros.

En una época como fue el abigarrado y complejo siglo XIX, una vez consumada la independencia, nuestro país y sus artistas se dieron a la tarea de reafirmar su propio ser e identidad, a la vez que buscaban no quedarse atrás en el concierto de las naciones civilizadas, todo ello producto de un encadenamiento de factores tradicionales y valores renovadores (Tibol, 1981, pp. 5-6). El nacionalismo hizo volver la mirada a lo propio, a nuestras raíces, mientras se deseaba entrar en concordancia con la modernidad y estar a la altura de las naciones más cultas, o como dice Justino Fernández (2001, p. 137), "El arte moderno del siglo xix significa que México realizó entonces su ideal histórico: ser sí mismo siendo como Europa."

Esa dicotomía se ve claramente en muchos artistas decimonónicos. Quizás los casos más paradigmáticos sean los del mexiquense José María Velasco (Moyssén, 2011, pp. 7-22) en la pintura y desde luego el del aguascalentense Jesús F. Contreras, en la escultura. Ambos artistas reclamados desde lo local, pero a la vez reconocidos como valores de trascendencia tanto nacional como internacional.

El presente artículo se focaliza fundamentalmente en el método biográfico (Fernández, 1990, pp. 55-68); al ser un estudio de carácter histórico centra su fortaleza en la investigación visual -abrevamos y nos beneficiamos de la consulta de un álbum fotográfico del bisnieto del escultor-, hemerográfica y documental en torno del artista, de tal manera que busca precisar y desmentir falsas atribuciones, con información que arroja nuevas luces sobre el escultor y su obra; tras el repaso de los principales autores que han escrito sobre sobre Jesús Contreras, se llega a inferencias de carácter hermenéutico sobre el "moldeado" de la personalidad del artista y la influencia que ejerció en su entorno, considerando condicionantes sociales e ideológicas. Para investigadores como Fausto Ramírez Rojas (1983) y Patricia Pérez Walters (1989, 2002, 2016a, 2016b), Contreras personificó toda una época en el arte y fue el más importante escultor mexicano de finales de la decimonovena centuria.

Así pues, el presente texto se inscribe en la línea de la historia cultural, y como consigna Ramón Reséndiz García (2013), al investigar una trayectoria se "pretende captar la totalidad de una experiencia biográfica, los

\footnotetext{
${ }^{1}$ Las cursivas son del original.
} 
cambios de vida, sus ambigüedades, sus dudas, sus contradicciones, la visión subjetiva y las claves que permiten la interpretación de los fenómenos sociales que acompañan la vida del sujeto" (p. 136).

\section{AÑOS MOZOS}

Son escasos los datos en torno a Jesús F. Contreras Chávez, en sus primeros años. Rodrigo Espinosa, redactor de El Republicano, ${ }^{2}$ apuntó:

Jesús F. Contreras nació en Aguascalientes el 21 de enero de 1866, siendo sus padres el Teniente Coronel Pedro C. Contreras y la señora Luz Chávez.

Del año de 1874 al 76 hizo sus estudios de primeras letras, en la escuela dirigida por el Sr. Plácido Jiménez; y en el mismo citado año de 76 estudió doraduría y dibujo, ingresando en el de 77 a la Litografía del Sr. Flores, de la que muy luego se hizo cargo; sin perjuicio de asistir por la noche a la escuela de adultos, donde fue distinguido con el premio que obtuvo por sus trabajos de caligrafía. ${ }^{3}$

Se han revisado archivos locales de Aguascalientes y no se han encontrado evidencias documentales de lo que asevera categóricamente la nota periodística. Llama la atención que se diga que entre sus diez y doce años haya hecho varias cosas que no suele hacer un chico de su edad; por ejemplo ¿no es extraño que un niño vaya a una escuela nocturna para adultos?

${ }^{2}$ En lo sucesivo, a los periódicos referidos les daremos el trato de documento, por lo que se citarán en formato extenso a pie, incluyendo en algunos casos la ciudad de edición, para mayor contexto. Hacemos la aclaración de que en la mayoría de los textos de prensa consultados no aparece el nombre de los autores. Cuando fueron consultados de la Hemeroteca Nacional Digital de México se colocan las siglas entre corchetes [HNDM] y en el caso de la biblioteca digital (Gallica) de la Bibliotèque Nationale de France $(\mathrm{BnF})$ colocaremos el enlace por la dificultad de su consulta.

${ }^{3}$ Rodrigo Espinosa. El señor Jesús F. Contreras. El Republicano. Periódico oficial del gobierno del estado. Aguascalientes, 10 de junio de 1888, p. 3; en adelante citado simplemente El Republicano. Cabe señalar que la semblanza fue tomada de un periódico capitalino, El Educador Práctico Ilustrado, del 10 de agosto de 1887 [HNDM], para reafirmar contundentemente que el joven estudiante era de Aguascalientes y por consiguiente el propósito fue desmentir lo aseverado por otros dos medios de la capital, El Siglo XIX y el Diario del Hogar, que ponían a Contreras como un "hijo de Coahuila" pensionado en París por el gobierno federal. 
Lo más probable es que siendo pequeño, en su terruño, recibiese clases particulares de su preceptor Plácido Jiménez, quien hacia 1844-1845 estudió en la Academia Municipal de Dibujo de Aguascalientes, institución que siguió el modelo francés y que no consideraba oportuno separar la enseñanza de las bellas artes y la de los oficios artesanales; de él sí que pudo haber recibido algún tipo de influencia con el tema del diseño. ${ }^{4}$

Ya adolescente, en su casa-mesón de la calle de Guadalupe, ubicada al norponiente de la ciudad, donde creció, moldeaba en cera figuritas de animales como mulitas y otros animales de carga que llevaban los arrieros; su diversión era ni más ni menos que un trabajo artesanal, relacionado con el oficio de su padre quien además de militar también era cerero; Martínez y Esparza (2016) señalan que observaba, diseñaba y realizaba figuras "como los que tenía a la vista" (p. 23). Su inteligencia, talento natural, así como su despierta imaginación creativa, se alimentaban de ese entorno.

Por otra parte, Jesús acudía de cuando en cuando a El Esfuerzo, taller de sus parientes los Chávez, establecimiento industrial que también fungía como enseñanza artística apoyada en manuales de dibujo. Estuvo matriculado en la Escuela Oficial de Niños, Número 1, plantel dirigido por su maestro Francisco Santini, quien enseñaba a partir de la "escuela objetiva" o sistema educativo en que el manejo del dibujo también era fundamental (Ramírez y Luévano, 2016, pp. 37-50). En uno y otro lado, aunado a su destreza manual, agilidad mental y sensibilidad artística, al jovencito de escasos quince años se le fue despertando el apetito por seguir aprendiendo y conocer nuevos horizontes. Años más tarde, las bases de sus aprendizajes técnicos familiares en Aguascalientes, sobre todo en el taller de los tíos, las potenciaría en las ciudades de México y París al terminar de formarse, como veremos.

Un episodio inesperado pronto le daría la oportunidad de cambiar de aires. Resulta que a principios de 1881, el señor Pedro Ciro Contreras -militar que había peleado a favor de la causa liberal en la revolución de Reformarecibió órdenes incontrovertibles de sus superiores de seguir prestando sus servicios a las armas nacionales en la capital del país; precedido de la fama de ser patriota, caballero, honrado y cumplido "en los deberes de su delicada misión", decidió llevarse a la familia consigo y se atrevió a hacer una petición

\footnotetext{
${ }^{4}$ Sobre el particular véase Ramírez (2016b, pp. 63-79).

${ }^{5}$ El teniente coronel Pedro C. Contreras falleció el 20 de febrero de 1893 y su madre Luz Chávez el 25 de noviembre de 1894, "[media] hermana del ilustre mártir de Malpaso C. José
} 
al Congreso de Aguascalientes, siempre preocupado por proteger e instruir a "los hijos de escasa fortuna del Estado", en el sentido de pedir una pensión para su vástago Jesús, de quince años, "quien está ya en aptitud de pasar ya a la instrucción secundaria, a fin de procurarse alguna carrera profesional"; 6 dado lo escaso de los fondos públicos, su solicitud fue denegada. A pesar de la respuesta negativa de parte de las autoridades aguascalentenses, la familia buscaría otras opciones y no se desalentaría. Nos dice Alain Luévano (2016), que "Jesús ya había visitado la Escuela Nacional de Bellas Artes y al echar el joven una simple mirada en el fascinante mundo de pintores, grabadores, escultores y arquitectos, decidió sin duda que era su destino" (p. 7), por lo que intentó su ingreso y logró ser admitido en la institución en julio de ese mismo año. Dada su notoria necesidad económica, no tardó en conseguir una pensión (véanse las imágenes 1 y 2 ).

De hecho, en su ciudad natal, pocos años después la elite política, social y cultural le llegó a reconocer como un orgullo, por ser "hijo de Aguascalientes", "aprovechado e inteligente" debido a sus capacidades, facultades y habilidades artísticas. Resulta que el joven Contreras, a la sazón estudiante en la ENBA, participó con varios trabajos en el certamen de la XXVIII Exposición de Industria, Minería y Artes del Estado de Aguascalientes, en abril de 1887; el jurado calificador le otorgó dos medallas, una de oro "por sus bajos relieves y demás objetos de bronce fundidos que presentó", de "verdadero mérito", y otra de plata "de primera clase" por "su busto retrato, tamaño natural, modelado en yeso"; esos premios, "bien merecidos", dice la nota, fueron otorgados a "quien conquista el genio y la aplicación por el sendero del progreso, en el perfeccionamiento", justamente en el ramo de las Bellas Artes.7

A la prensa local no le pasó desapercibida la carrera del artista, ya que publicó que el joven Contreras "hijo de este Estado", sufrió un penoso accidente en la ciudad de México. De manera sucinta comentó que precisamente cuando el estudiante apoyaba en las maniobras a Miguel Noreña, su maestro

María Chávez, quien siendo gobernador constitucional de este Estado, fue sacrificado por las huestes invasoras el 5 de abril de 1864", véase notas necrológicas en El Republicano, el 26 de febrero de 1893, p. 3 y 2 de diciembre de 1894, p. 3, respectivamente.

${ }^{6}$ El C. Pedro C. Contreras solicita al Honorable Congreso del Estado de Aguascalientes una pensión para que su hijo Jesús estudie instrucción secundaria en la ciudad de México. 15 de marzo de 1881. Fondo Poder Legislativo. Caja 34. Expediente 12. Archivo Histórico del Estado de Aguascalientes.

${ }^{7}$ Premios. El Republicano. Aguascalientes, 29 de mayo de 1887, p. 3. 

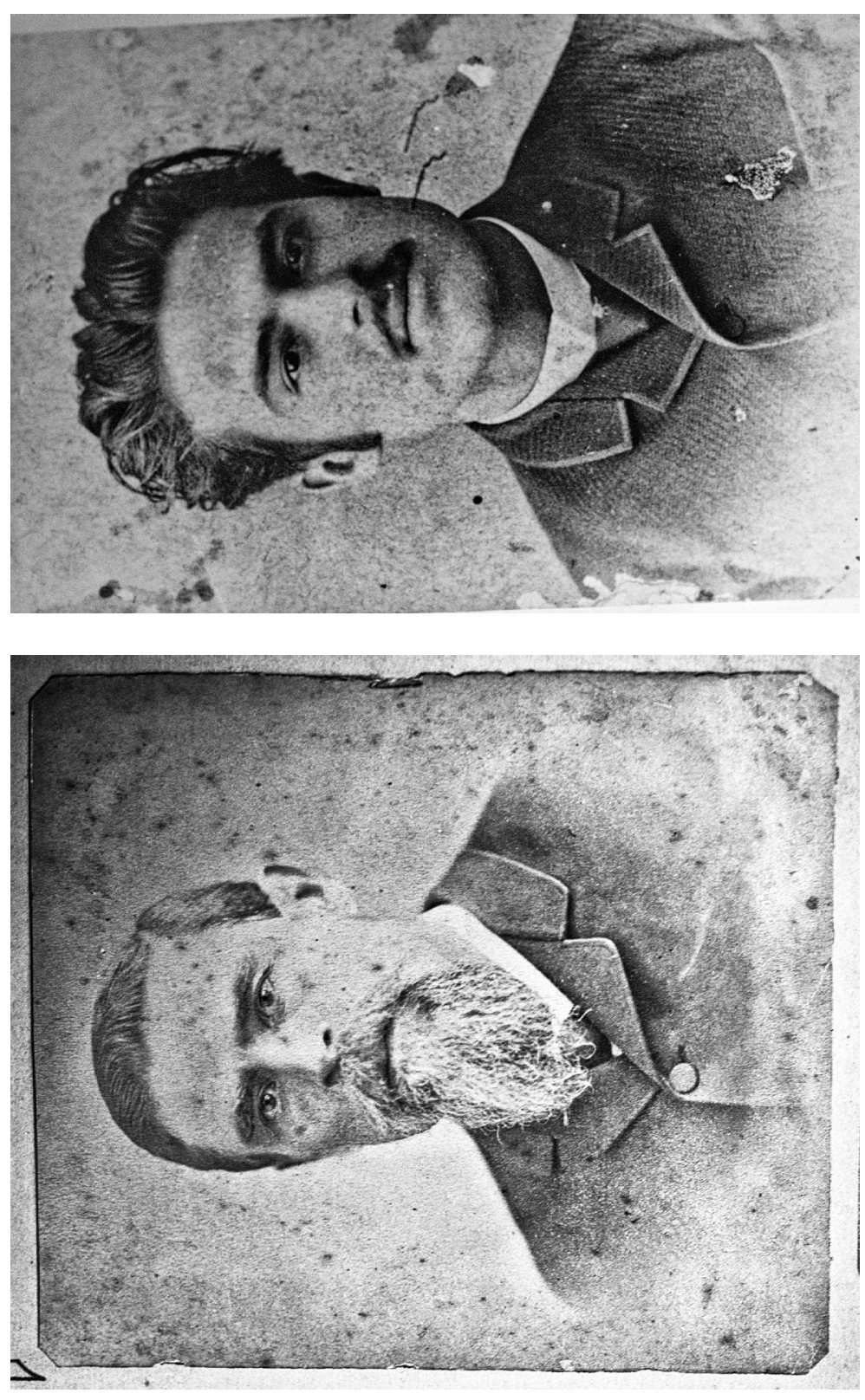

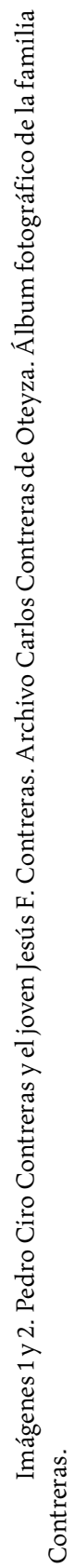


de escultura en la ENBA, autor de la estatua de Cuauhtémoc, al estar vaciándola, "se reventó el crisol en que se fundía el bronce, cayéndole el candente metal en los pies causándole horribles quemaduras". La redacción de El Republicano deseaba un pronto restablecimiento "al expresado joven Contreras de tal accidente". 8

Por otro lado, hacia el 20 y 21 de octubre de 1887, cuando realizaba una visita de cortesía por Aguascalientes Mr. Talbott (rico publicista estadunidense, editor y dueño de Rail Way Age, que viajaba en lujoso ferrocarril o "Carro-Palacio" del mismo nombre) y su esposa, fueron llevados por una comitiva de distinguidos aguascalentenses al Instituto Científico y Literario, y al entrar a la secretaría del establecimiento, "admiraron los viajeros unos preciosos cuadros del joven Contreras, alumno de la Academia de San Carlos y sobre todo una Virgen de la Silla, que materialmente subyugó" a la mujer; queriendo quedar bien con los estadunidenses, uno de los profesores - no fue mencionado su nombre- sin más trámite "descolgó el precioso cuadrito y lo ofreció a la Sra. Talbott a nombre de los catedráticos y en recuerdo de su visita al instituto".

También de ese año hay que mencionar un hecho hasta ahora no consignado, y es que precisamente "por ser hijo del estado de Aguascalientes" y gracias a los méritos antes enunciados, el Congreso local le otorgó un apoyo de 100 pesos para que completara el pago de su primer viaje a Europa, ya que el Ministerio de Justicia e Instrucción Pública sólo le había proporcionado 150, "que no son suficientes ni para un pasaje de tercera". ${ }^{10}$ Es curioso que uno de los diputados firmantes de la resolución, Rafael Sagredo, se convertiría posteriormente en pariente político del escultor, pues era tío carnal de su futura esposa, Carmen Elizondo Sagredo.

${ }^{8}$ Accidente. El Republicano. Aguascalientes, 2 de octubre de 1887, p. 4. Para apoyar a Noreña, Contreras había pedido licencia a las autoridades para ausentarse de la Escuela Nacional de Bellas Artes (ENBA), del 15 de abril al 15 de agosto de 1887; ¿cuándo ocurrió exactamente el accidente? Las fechas de la colaboración, permisos, solicitud de no perder la pensión y demás, que consigna Pérez Walters (1989) son un tanto confusas (pp. 35-37 y nota 59, p. 242). La autora, además, considera exagerada la versión.

${ }_{9}$ Variedades. La recepción de Mr. Talbott. El Instructor, 1 de noviembre de 1887, Aguascalientes, pp. 6-11.

${ }^{10}$ Carta personal de Jesús Contreras al Congreso de Aguascalientes. 9 de noviembre de 1887. Fondo Poder Legislativo. Caja 54. Exp. 12. Archivo Histórico del Estado de Aguascalientes, México. La resolución legislativa así como la solicitud de Contreras fueron localizadas por el maestro Alain Luévano Díaz, a quien agradecemos el dato. 


\section{IR Y VENIR ENTRE MÉXICO, PARÍS Y LA PATRIA CHICA}

La vida en la capital debió haberlo fascinado, pues era entonces -y sigue siendo- fuente de poder político, que irradia ideas, impone estilos, difunde modas; conforme pasaban los años, Contreras fue alterando sus costumbres, hábitos, diversiones, formas de vestir, en una gran urbe que no dejaba de crecer, con sus barrios tradicionales, colonias nuevas y zonas residenciales, a donde llegaban publicaciones periódicas procedentes del extranjero (Speckman, 2006, pp. 17-47).

De allí la importancia de mirar a Europa, particularmente Francia y específicamente París, la deslumbrante y cosmopolita Ciudad Luz, entonces epicentro del arte, a la que fueron a parar escritores y artistas, donde "en distintas épocas, coincidieron y convivieron un buen número de nuestros modernistas" (Ramírez, 1983, pp. 124-125).

El acucioso historiador del arte Fausto Ramírez (1983, p. 118), ubica a Jesús F. Contreras precisamente en la generación de los modernistas, esto es, a los artistas nacidos entre 1860 y $1874 .{ }^{11}$ Pero, ¿qué fue lo que caracterizó a dicha generación? Veamos. Nos dice el investigador del Instituto de Investigaciones Estéticas de la Universidad Nacional Autónoma de México: "Los modernistas pasaron por los salones de la Academia en los años ochenta y principios de los noventa. Vivieron la euforia nacionalista de la etapa de la consolidación del régimen porfirista, y también la derivación hacia el cosmopolitismo experimentada en los años postreros" (Ramírez, 1983, pp. 118-119).

El régimen del general Porfirio Díaz se estabiliza y comienza a consolidarse. Por ello necesitaba labrarse una imagen de avance y progreso. Por tanto, Contreras fue enviado a Europa, donde terminó de formarse justamente en París, no en la Escuela de Bellas Artes, sino en los muy reputados talleres de fundición de esa ciudad, donde tuvo oportunidad de trabajar y formarse en la práctica operativa y la técnica, ${ }^{12}$ además de relacionarse con los artistas y

${ }^{11}$ Da una larga lista de pintores, escultores, arquitectos e ingenieros. Entre los más destacados menciona, en la pintura, a: Joaquín Clausell, Germán Gedovius, Leandro Izaguirre, Alberto Fuster, Julio Ruelas y otros; escultura: Enrique Guerra, Agustín Ocampo y Guillermo Cárdenas; en arquitectura e ingeniería: Carlos Noriega, Carlos M. Lazo, Nicolás Mariscal, etcétera.

${ }^{12}$ Véase el informe que rindió Jesús F. Contreras a su regreso, en Catálogo de la Escuela Nacional de Bellas Artes, 1857-1920, Sánchez (1996), pp. 69-72; al parecer también visitó mu- 
escultores más importantes del momento; desde luego también visitó algunos museos y observó edificios. Siendo todavía estudiante realizó los altorrelieves de los dioses y reyes del Pabellón Azteca que presentó México en la Exposición Universal de 1889 (García Robles, 2016a; 2016b, pp. 198-215; Rodríguez, 2013). ${ }^{13}$

La prensa de Aguascalientes no lo perdía de vista y estaba al pendiente de cualquier noticia. El Republicano transcribió: "El joven Jesús F. Contreras, pensionado en París por el Gobierno de México, acaba de hacer un notable busto del arquitecto Mr. Colibert, autor de las obras de construcción de la antigua Bastilla. Dicho busto, lleno de expresión y energía, dice un periódico parisiense, honra al joven artista, y hace concebir las más lisonjeras esperanzas de su talento." Y agregó: "Las anteriores líneas las hemos tomado de 'La Crónica', suplemento al ilustrado colega El Álbum de la Mujer, y nos hemos apresurado a insertarlas por tratarse de nuestro amigo y paisano, el Sr. Jesús F. Contreras, a quien sinceramente felicitamos por el triunfo artístico que acaba de obtener en el extranjero." ${ }^{14}$

En pleno potencial creativo, el escultor decidió contraer matrimonio (véase imagen 3). Volvió a su ciudad natal a principios de 1891 para casarse con una muchacha de familia medianamente acomodada, la también aguascalentense Carmen Elizondo Sagredo, hija del poeta y funcionario público de origen español Blas Elizondo Pérez ${ }^{15}$ y de Josefa Sagredo García Rojas. ${ }^{16}$ La ceremonia civil fue el día 1 de enero, siendo sus testigos Carlos y Rafael Sagredo, ambos dijeron ser comerciantes (tíos maternos de la novia), ${ }^{17}$ y Juan

seos, monumentos y fundiciones en otras ciudades europeas como Madrid, Londres, Bruselas, Berlín y Viena.

${ }^{13}$ María G. Rodríguez hace un comparativo de ambas participaciones, la primera en tanto estudiante y la segunda ya como un artista reconocido. Marco Antonio García Robles, por su parte, da cuenta de la decoración escultórica del Pabellón Azteca que México montó para la Exposición Universal de ese año; tocó al escultor aguascalentense traducir el programa político-ideológico del régimen en seis deidades prehispánicas así como seis reyes y "héroes" mexicas.

${ }^{14}$ Artista mexicano. El Republicano, 27 de mayo de 1888, Aguascalientes, p. 3.

${ }_{15}$ Para una semblanza de este personaje, véase a Tiscareño (2016). Con base en fuentes pertinentes, reconstruye la trayectoria del suegro de Jesús F. Contreras, esto es, procedencia, empleos, vena poética -dedicada a niños, sus hijos y esposa (se casó con Josefa Sagredo García Rojas en 1865) principalmente-, así como relaciones familiares y atmósfera cultural en el Aguascalientes de entonces.

${ }^{16}$ Para una amplia monografía sobre los García Rojas véase Reyes (2002).

${ }^{17}$ Semblanza de Rafael Sagredo, en Engel (1997, p. 371). Había incursionado en la política, como diputado local, federal y gobernador interino en varias ocasiones. 


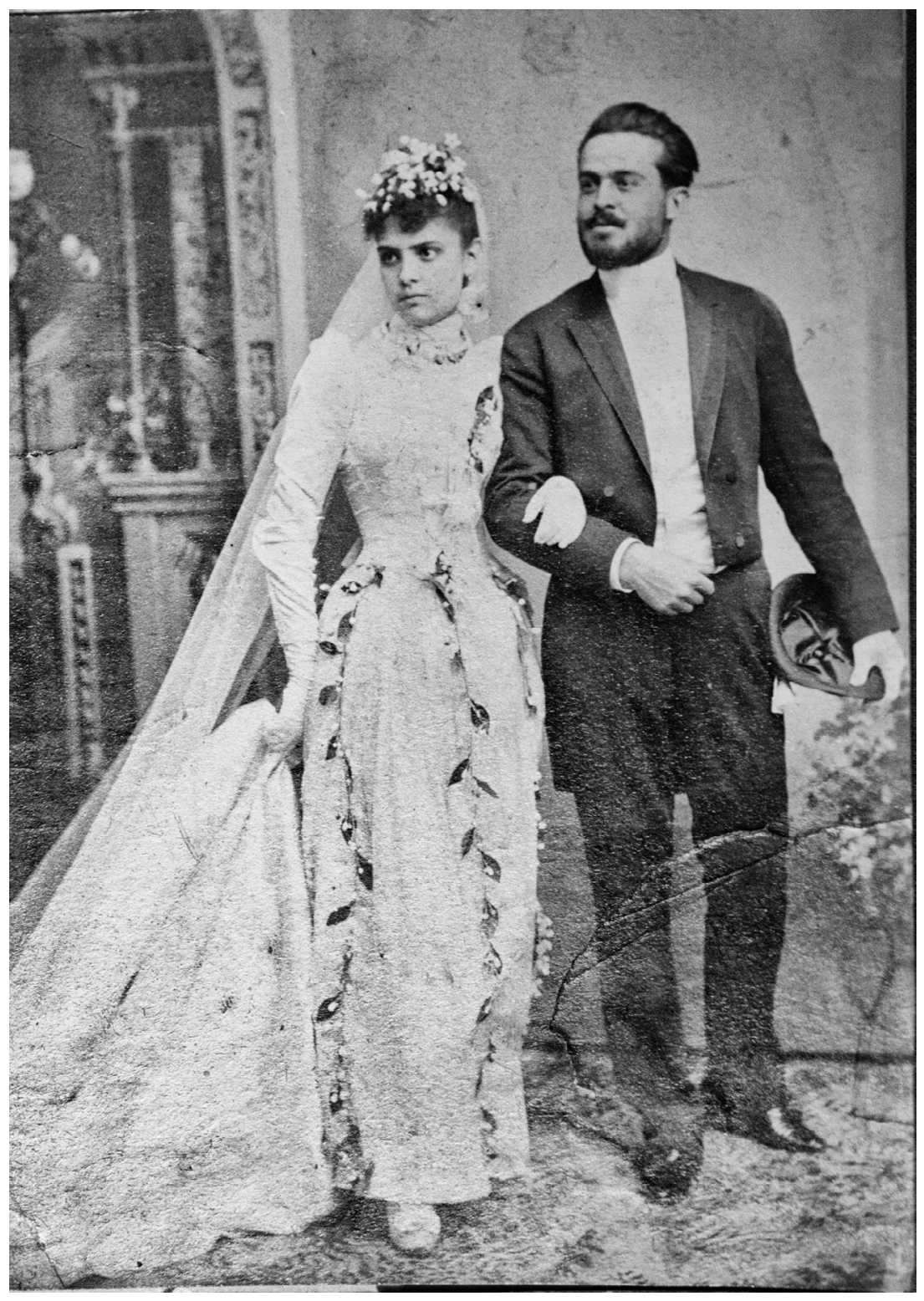

Imagen 3. Jesús F. Contreras Chávez y Carmen Elizondo Sagredo el día de su boda. Archivo Carlos Contreras de Oteyza. Álbum fotográfico de la familia Contreras. 
B. Chávez, quien manifestó tener como oficio ser carnicero (primo del novio, pues era hijo del ex gobernador liberal José María Chávez fusilado por las fuerzas extranjeras durante la invasión francesa), y futuro socio, como veremos. ${ }^{18}$

Por la iglesia se casaron una semana después, el 8 de enero de 1891, en la capilla del Sagrado Corazón, anexa a la iglesia parroquial de la Asunción (hoy catedral); los casó el presbítero Francisco de P. Díaz; Jesús manifestó tener 25 años de edad, "originario de esta ciudad y vecino de la ciudad de México hace diez años, habiendo permanecido en varios puntos de Europa dos años"; Carmen tenía 18; en el acta de matrimonio eclesiástico dice: "Se practicaron las diligencias respectivas, se confesaron, comulgaron, están instruidos en la doctrina cristiana y en las obligaciones de su estado, se amonestaron en esta iglesia parroquial...", fueron testigos de velas su tío el doctor Ignacio Toribio Chávez (gobernador interino y luego constitucional entre 1871 y 1872, padre de Ezequiel A. Chávez, filósofo, político y educador, futuro rector de la Universidad Nacional) y su cuñado Tibaldo Elizondo; sus padrinos, el doctor Guadalupe Ortega y Cecilia Bolado. ${ }^{19}$ El Instructor, periódico cuyo director y propietario era el doctor Jesús Díaz de León, miembro de la elite local, ${ }^{20}$ el 1 de febrero de 1891 publicó: "El mismo día se verificó también la ceremonia matrimonial de nuestro buen amigo Jesús F. Contreras, con la simpática joven Carmen Elizondo, marchando a México esa mañana, después de la ceremonia, los recién casados. Que una eterna felicidad guarde el hogar de los desposados" (p. 8).

Fue así como se dio la unión de dos personas cuyos orígenes, procedencia e historia no era tan distinta una de la otra, en tiempos donde el estatus de clase era una condicionante de la vida social en una ciudad tradicionalista. La añeja relación de amistad entre ambas familias, los Contreras Chávez y los Elizondo Sagredo (ambas de viejo cuño liberal), se vio coronada con la unión religiosa y civil.

${ }^{18}$ Registro Civil. Matrimonios. 1891, foja $1 \mathrm{fte}$. Archivo Histórico del Estado de Aguascalientes (en adelante AHEA), México.

${ }_{19}$ Sagrario de Aguascalientes. Matrimonios. Libro 41, foja $132 \mathrm{fte}$. Archivo de la Mitra del Obispado de Aguascalientes (en adelante AmoA), México.

${ }^{20}$ Jesús Díaz de León, médico culto y erudito, impresor plurilingüe, periodista cultural, catedrático del Instituto de Ciencias, diputado local, miembro de la elite cultural aguascalentense dirigió por muchos años el periódico El Instructor (1884-1910) en el que divulgó al gran público los beneficios de la ciencia con espíritu cosmopolita y visión enciclopédica. Véase Gómez (2006, pp. 9-23) y Fernández (2006, pp. 25-39). 
A su regreso a México, se vinculó con lo más granado de la elite intelectual de esa época, principalmente a través del Ateneo Mexicano Literario y Artístico. Se relacionó con escritores de la talla de Jesús E. Valenzuela, Jesús Urueta, Luis G. Urbina, Amado Nervo, Federico Gamboa, José Juan Tablada, Rubén M. Campos, Gerardo Murillo, José F. Elizondo, entre otros. También cultivó amistad con parte de la clase política (Pérez Walters, 1989, p. 89); incluso fue amigo personal del general Porfirio Díaz, primer magistrado de la nación y del maestro y educador Justo Sierra, entonces ministro de la Suprema Corte de Justicia, de la cual fue presidente, más tarde nombrado subsecretario de Instrucción Pública en 1901, y en 1905 secretario de Instrucción Pública y Bellas Artes, quien no dudó en recomendarlo ante diversos personajes, al igual que a sus allegados. ${ }^{21}$

Patricia Pérez Walters (2016a) -sin duda la máxima especialista en el quehacer y personalidad artística del escultor-, analizó los aspectos técnicos que Contreras asimiló como becario en varios talleres parisinos, permitiéndole aplicar esos conocimientos en nuestro país en respuesta a las necesidades del Estado mexicano en cuanto al uso social e ideológico de la escultura como vehículo de cohesión política, todo ello en una época en que la llamada "epidemia de estatuomanía" experimentada durante la segunda mitad del siglo XIX consistió en que la estatuaria se adueñó tanto de los espacios urbanos como de los domésticos, fenómeno que se extendió por las capitales de todo el orbe y que surgió de la carga didáctica que el pensamiento liberal burgués confirió a los monumentos públicos. La autora subraya el carácter diversificado que el artista Contreras imprimió a su actividad productiva -tanto escultórica como de piezas ornamentales-en México, precisamente con una mentalidad empresarial (pp. 68-83).

Esculturas que fueron pensadas, diseñadas, moldeadas y fundidas en la Fundición Artística Mexicana, fueron sembradas en varias de las capitales más importantes del país, como Puebla, Guanajuato, Saltillo y desde luego la

${ }^{21}$ Por ejemplo, podemos dar cuenta de las atenciones brindadas al escultor, a Jesús Valenzuela y al pintor Leandro Izaguirre, por José López Portillo y Rojas, miembro de la elite jalisciense. También existe testimonio de la recomendación que le brindó Sierra al cuñado de Contreras, Emilio Elizondo, ante Joaquín D. Casasús, presidente de la Cámara de Diputados. La misiva de López Portillo en Fondo Justo Sierra. Libro 3, documento 32, folio 145. Archivo Histórico de la unam (en adelante ahunam), México. La carta de Casasús en Fondo Justo Sierra. Libro 3, documento 28, folio 140. Ahunam, México. 
ciudad de México. Particularmente relevantes son las que hizo para el Paseo de la Reforma, acordes con el discurso del liberalismo triunfante (Martínez Assad, 2005, pp. 8-39). El diario El Imparcial, periódico de circulación nacional que siempre mostró adhesión al régimen porfirista, hizo un rápido recuento de la obra escultórica de Contreras:

Muchas de las estatuas que se han erigido en los andenes del Paseo de la Reforma, son obra suya; llevan su firma las figuras ecuestres de Zaragoza y Bravo y el monumento franco-mexicano de Puebla; ${ }^{22}$ el González Ortega de Zacatecas; la Corregidora de Querétaro, que orna el jardín de Santo Domingo; “iMalgré tout!" que obtuvo el gran premio en París, en 1900; gran número de bustos de hombres célebres nacionales; el hermoso proyecto del monumento a Manuel Acuña y el de una fuente suntuosa para el Paseo de la Reforma. ${ }^{23}$

Este programa escultórico tenía un alto valor decorativo y simbólico, con una clara idea cohesionadora de la historia de la nación, en apoyo a una política cultural nacionalista. Se trata de "monumentos de intención celebratoria y oficial que, en forma más o menos realista, representan a próceres de la historia nacional o alegorías patrióticas" (Ramírez, 1983, p. 139).

En tan sólo una década, desplegó una capacidad de trabajo impresionante. Pero Jesús F. Contreras no se olvidó de acudir cada vez que podía a su patria chica. En la primavera de 1891 de nuevo concursó y ganó en la Exposición de Bellas Artes de Aguascalientes ${ }^{24}$ (véase imagen 4), donde aprovechó para exhibir sus trabajos ornamentales y numismáticos.

Ya con cierto reconocimiento a nivel nacional, el escultor -acompañado de varios de sus discípulos tanto de la ENBA como de la Escuela Nacional

${ }^{22}$ Como se señalará más adelante, no fueron pocas las falsas atribuciones de obras a Contreras. El monumento franco-mexicano, ahora en el Panteón Francés de Puebla, es uno de esos casos, pues los autores son Auguste Leroy y Marcel Desbois.

${ }^{23}$ Muerte del escultor Jesús F. Contreras. El Imparcial, 13 de julio de 1902, México, D.F., p. 2. [HNDM].

${ }^{24}$ Sobre el particular véase Terán Fuentes (2011). La autora afirma que este tipo de certámenes se hacía en Aguascalientes "para hacer acto de presencia y tener su propia proyección, aunque fueron muy modestos", cuyas intenciones por parte de sus promotores fue en todo momento "buscar la grandeza, exhibir los logros del intelecto humano en el ámbito local", cuyo objetivo principal fue "difundir una idea de nación, vinculada a los tópicos del trabajo, de la paz, del progreso, de la civilidad, de la ciencia, que se relacionaban con corrientes filosóficas y sociales del pensamiento europeo...", pp. 3 y 5. 


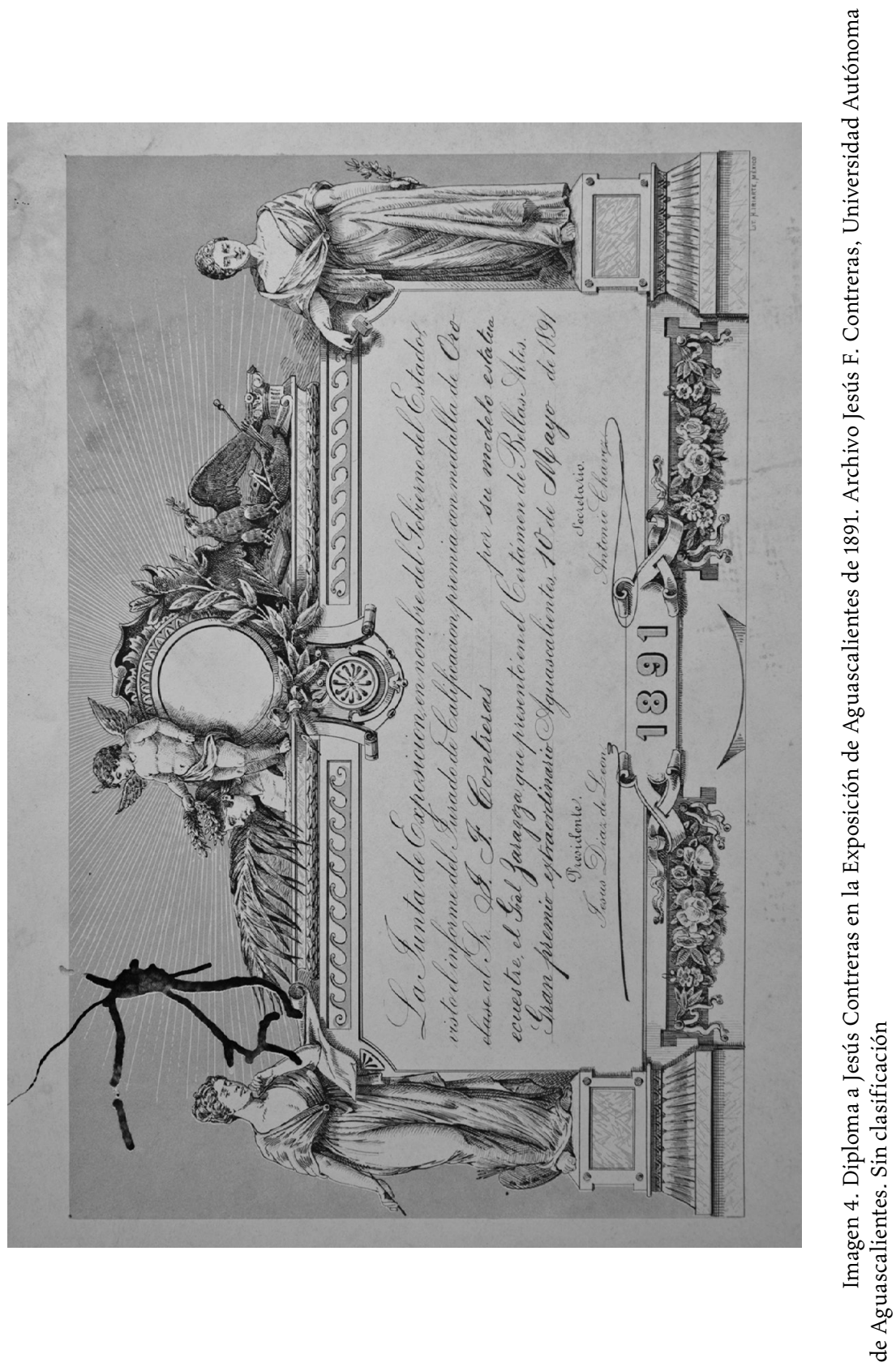


de Artes y Oficios, quienes también resultaron galardonados- expuso varias piezas, siendo la más importante el modelo en yeso de la estatua ecuestre del general Ignacio Zaragoza (véanse imágenes 5 y 6), cuya fundición casi por duplicado ${ }^{25}$ se haría poco después para ser ambas esculturas colocadas en las ciudades de Puebla y Saltillo, en un afán del régimen por fomentar una pedagogía cívica de corte liberal (Terán, 2016, pp. 140-155).

A mediados de año, exactamente el 3 de julio de 1891, esto es, a escasos seis meses de su boda y dos de haber ganado en la Exposición de Bellas Artes de Aguascalientes, fallece su suegro el señor Blas Elizondo Pérez, "víctima de una terrible enfermedad", quien fuera integrante de la elite social y cultural aguascalentense ${ }^{26}$ al igual que su esposa Josefa Sagredo García Rojas (véanse imágenes 7 y 8). Nada dice la prensa si los recién casados acudieron al funeral.

Un año después, para mediados de 1892, el escultor pasó de nueva cuenta por Aguascalientes, como lo registró la prensa local: "De regreso de Europa, hemos tenido el gusto de saludar a este buen amigo y paisano, que permaneció unos cuantos días en esta ciudad, de donde partió para la capital de la República. Los importantes asuntos que lo llevaron al viejo mundo, obtuvieron un éxito completo, por lo cual lo felicitamos sinceramente." ${ }^{27} \mathrm{En}$ realidad, Contreras había sido enviado desde febrero por el general Díaz, su futuro socio, con el cometido de comprar "todo lo necesario para la instalación de una fundición artística” en la capital de México (Sánchez, 1996, p. 142); este hecho marcaría el inicio de la carrera del escultor como artista-empresario, tal como apunta Pérez Walters en sus trabajos.

En esos años desplegó una notable capacidad de trabajo, innovó y emprendió con gran tenacidad y talento artístico nuevas formas creativas. De fuerte vocación empresarial, hacia 1895 Contreras estableció un nuevo nego-

${ }^{25}$ Se les ha considerado estatuas gemelas, pero entre ambas estatuas ecuestres hay variaciones en las posiciones de las patas de los caballos, así como en la postura de los brazos del general Zaragoza.

${ }^{26}$ La larga nota necrológica de Blas Elizondo Pérez (1841-1891) lo presume como proclive a los círculos literarios, de origen español, nacionalizado mexicano que al ser un liberal instruido se distinguió por "sus virtudes, su patriotismo..., su ilustración y sus ideas progresistas"; "poeta sentimental", orador en "festividades cívicas", periodista y redactor del periódico oficial del gobierno del estado durante varios años, ejemplar y honrado funcionario público que se había desempeñado también como "Administrador local de Correos de esta capital". En La muerte del Señor Blas Elizondo. El Republicano, periódico oficial del gobierno del estado, 12 de julio de 1891, Aguascalientes, p. 1.

${ }^{27}$ El Sr. Jesús F. Contreras. El Republicano, Periódico Oficial del Gobierno del Estado, 19 de junio de 1892, Aguascalientes, p. 3. 


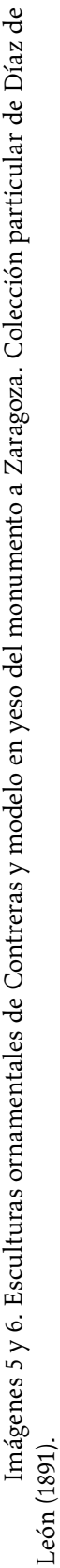




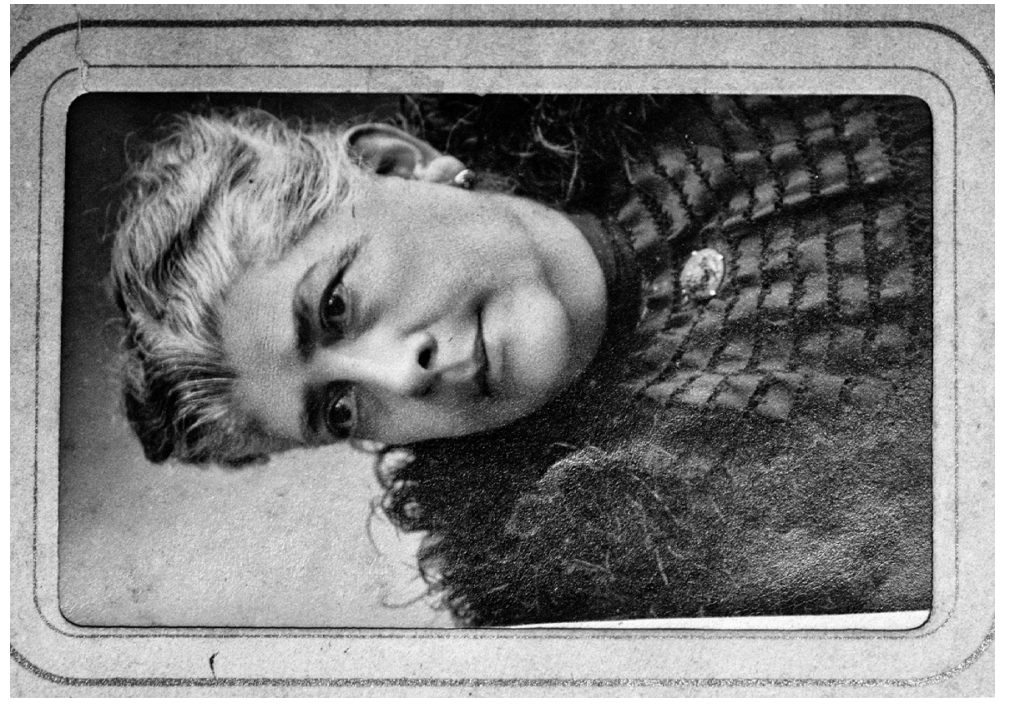

No

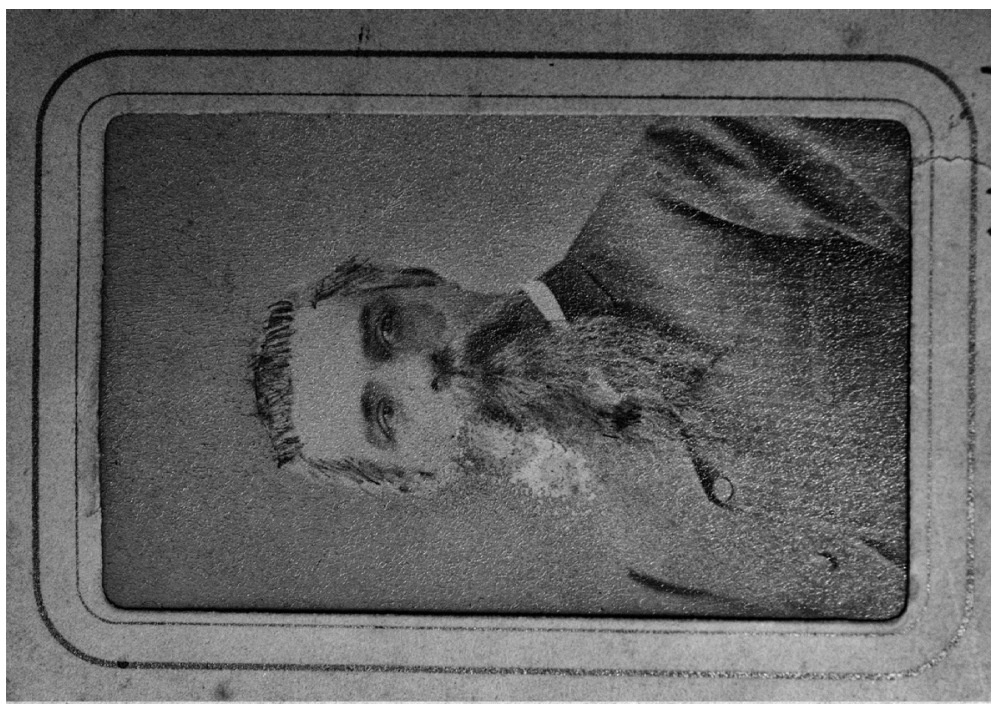

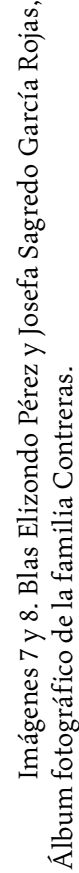


cio: el Taller de Alfarería Artística (dentro de las instalaciones de la Fundición Artística Mexicana), donde se fabricaron de manera seriada una amplia variedad de objetos ornamentales de lujo y demás detalles decorativos para salones, jardines y espacios tanto para casas de clase media como para residencias de la alta: pequeñas esculturas de cuerpo entero, bustos, vasos, jarrones, ánforas, tazas; figuras alegóricas para fuentes (amorcillos, animales), grifos, remates, etc. Los materiales, de los más variados: porcelana, terracota (de apariencia natural o terminado simulando bronce y mármol), así como mayólica. Contreras advirtió que la creciente burguesía de la sociedad porfiriana -con el afrancesamiento que la caracterizaba, aunque también se percató de las vanguardias y preferencias por los estilos griego-clásico, alemán de gran tradición, chino y japonés en boga a finales del siglo XIX-aspiraba a adoptar satisfactores de la vida refinada y buen gusto, en un querer sentirse modernos y cosmopolitas; en el taller trabajaron algunos de sus discípulos así como maestros empíricos fogueados en el arte del retrato (Pérez Walters, 2016b, pp. 34, 41, 54-55, 256-266, 286, 414, 417; Encino y Gómez, 2016, pp. 96-109). ${ }^{28}$ El Taller de Alfarería Artística del escultor quedó bajo la dirección de su hermano Baudelio, menor por cinco años, cuando Jesús partió para Europa a fines de 1898 con el propósito de tratarse del problema que aquejaba su brazo derecho, víctima del cáncer; como sabemos, a fin de cuentas y para evitar mayores complicaciones, le fue amputado.

Lejos de amilanarse, sacó fuerzas de flaqueza. Jesús Contreras, "legítima gloria mexicana" e "hijo de Aguascalientes", triunfó en la Exposición Universal de París de 1900 -verificada del 7 de abril al 5 de noviembre-, recibió la más alta condecoración artística -el Grand Prix de escultura -y obtuvo el pleno reconocimiento de sus compatriotas y paisanos. El relato de la calificación oficial de las obras artísticas mexicanas no ha sido consignado desde entonces, pero aparece en el periódico parisino La Justice:

El jueves por la mañana, 14 de los corrientes, el jurado de escultura se presentó en el pabellón [de México]. En previsión de esta visita, el Sr. Sebastián B.

${ }^{28}$ Las autoras, Enciso y Gómez, plantean el supuesto de que, influenciado por el contexto europeo durante su formación de 1887 a 1889 en París, el escultor-empresario desarrolló una postura innovadora respecto a lo que se vivía en el medio artístico e industrial en México durante esa época. Encuentran una serie de relaciones entre la ideología de los considerados pioneros del diseño en Europa y las reflexiones respecto a las artes aplicadas que Contreras manifestó en algunos de sus escritos y proyectos. 
de Mier [delegado de México en dicha exposición] había rogado a Bartholdi, el eminente autor de la estatua de La Libertad iluminando al Mundo, que sirve como el faro principal en Nueva York, que representara en esta ocasión su gobierno. El maestro había aceptado con mayor presteza, puesto que uno de sus mejores alumnos, el Sr. Jesús F. Contreras, es mexicano y expositor.

Después de su revisión, los artistas ilustres que componían el jurado, franceses y extranjeros, expresaron el deseo de ver personalmente al Sr. Jesús F. Contreras y la fotografía de sus trabajos anteriores, algunos de los cuales adornan notablemente las ciudades de México y Puebla. El escultor mexicano que se había apartado discretamente, recibió las felicitaciones más favorecedoras. Es todavía un hombre joven, que fue puesto a prueba por la pérdida de su brazo derecho, pero que, a pesar de todo, un futuro hermoso le parece reservado, porque en él el diseño noble combina con la ejecución viva.

El jurado de pintura anunció su venida, y ya el Sr. Sebastián B. de Mier cuenta con la asistencia de un miembro del Instituto, M. Bouguereau, ${ }^{29}$ que lo representará.

Como en los Estados Unidos y en todo el Nuevo Mundo, el arte nace en México, y es imposible predecir lo que le ofrecerá más adelante. ${ }^{30}$

Sólo ocurrió un detalle que más que manchar la imagen de Contreras, seguramente tuvo que ver con la lucha política local, pues resulta que un periódico de Aguascalientes - cuyo nombre no fue revelado-publicó en una columna la nota en que se aseveraba que "el señor Jesús F. Contreras recibe del Erario del Estado una subvención de doscientos cincuenta pesos mensuales", por representar en calidad de delegado al pabellón de Aguascalientes en dicha exposición. Dado que el gobernador era Carlos Sagredo ${ }^{31}$ (véase imagen 9), tío de su esposa, no se quiso dar lugar a sospechas de ninguna especie y

${ }^{29}$ Es pertinente mencionar que tanto Bartholdi como Bouguereau intercambiaron con Contreras afiliaciones a las sociedades de artistas francesa y mexicana, aunque luego se presentaron diferendos que pueden indagarse en la documentación del Archivo Jesús F. Contreras de la Universidad Autónoma de Aguascalientes, donde se conserva la medalla que el gobierno mexicano debió entregar precisamente al autor de la Estatua de la Libertad.

${ }^{30}$ L'Exposition Mexicaine. La Justice, 18 de junio de 1900, París, p. 1. (Traducción y cursivas nuestras). Recuperado de biblioteca digital Gallica de la Bibliotèque Nationale de France http://gallica.bnf.fr/ark:/12148/bpt6k8255637/f1.item.r=\%22jesus\%20f

${ }_{31}$ Carlos Sagredo fue un comerciante y político, miembro de la elite de Aguascalientes, ocupó el cargo de diputado local en las legislaturas XIX y XX, y fue gobernador en el periodo 1899-1903. Delgado (2007, pp. 52, 54-55). 


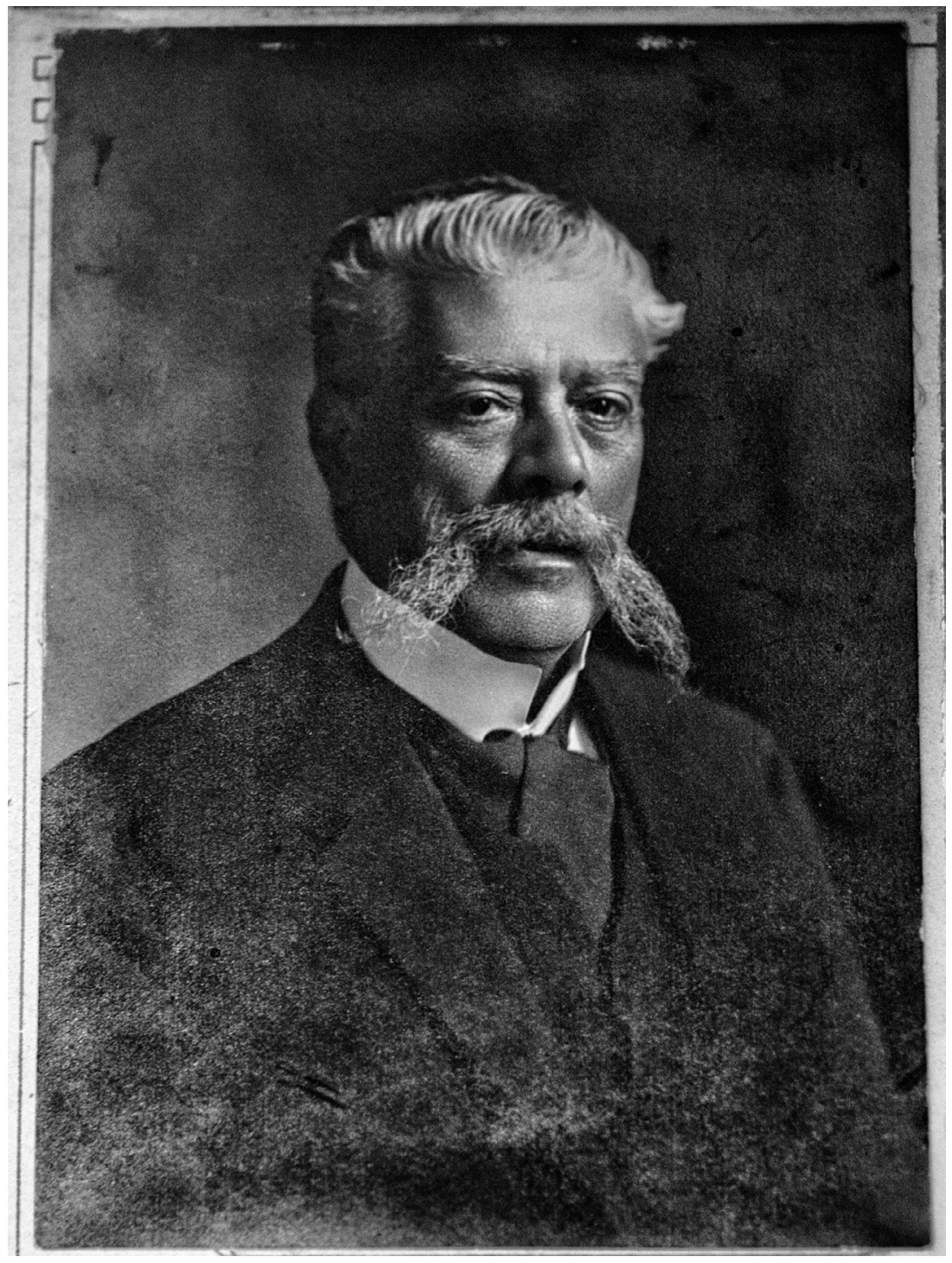

Imagen 9. Carlos Sagredo, gobernador de Aguascalientes 1899-1903. Archivo Carlos Contreras de Oteyza. Álbum fotográfico de la familia Contreras. 
apareció en el periódico oficial el desmentido, esto es, una nota políticamente correcta para aclarar la inexactitud:

Es cierto que el señor Contreras fue agraciado por el Gobierno con aquella representación, pero sin retribución de ninguna especie, pues como hijo de Aguascalientes, ofreció desempeñarla gratuitamente en nota de 3 de marzo último.

En esta misma fecha el señor Contreras solicitó una pequeña ayuda pecuniaria para gratificar a alguna persona que le impartiera su cooperación en el arreglo y clasificación respectivas de los objetos pertenecientes a este Estado, destinados al citado Pabellón, y la H. Legislatura, creyendo justa la petición, acordó se le ministrara por una sola vez, la cantidad de doscientos cincuenta pesos, es decir, por un periodo de cerca de siete meses que durará el Certamen Universal de París... ${ }^{32}$

Es posible que, para evitar este tipo de suspicacias, el citado gobernador Sagredo encargara a otro escultor la manufactura de la efigie de Benito Juárez, inaugurada en septiembre de 1902, apenas dos meses después de la muerte de Jesús Contreras. ${ }^{33}$ Empero, no deja de llamar la atención que justamente el artista Federico Homdedeu, el artífice del monumento colocado en la plaza principal de la capital de Aguascalientes (Delgado, 2007, p. 12), fuese uno de los principales colaboradores del aguascalentense y muy probablemente, coautor de algunos bronces ornamentales. ${ }^{34}$ Un busto que pudo haber surgido de esta mancuerna, es el dedicado a Jesús Terán, salido de la fundición de los Contreras y develado en 1907, aunque tiene grabado el año de 1899.

Una interesante nota signada con el seudónimo "M.A.Z. DE B", ${ }^{35}$ en tono entre triunfalista y catastrofista anotaba:

32 Aclaración. El Republicano, 26 de agosto de 1900, Aguascalientes, p. 2.

${ }_{33}$ Es menester puntualizar que este tipo de obras se encargaban con meses o incluso años de antelación.

${ }^{34}$ Por lo menos se tiene registrada la colaboración en la estatua de Josefa Ortiz de Domínguez, colocada en la plaza de Santo Domingo en el Centro Histórico de la Ciudad de México.

${ }^{35}$ M.A.Z DE B, posiblemente sea el seudónimo de Sebastián B. de Mier, delegado de México en la Exposición Universal de París de 1900; fue publicada en Le Nouveau Monde, París, el 26 de agosto de ese año, de acuerdo con lo que anota Pérez Walters (2016b, p. 330, notas 98 y 99); la misma nota en la sección "Nuestros Artistas", en La Evolución Americana, 
Jesús Contreras es mexicano; y cuando el arte a que ha consagrado su existencia comenzaba a otorgarle sus favores, el destino cruel le hirió, arrebatándole el brazo derecho, esto es, privándole de la mano que daba al barro, al mármol, al bronce, la vida de la idea estética.

Mas no es Contreras de los hombres a quien la desgracia abate, pertenece a la raza de los luchadores, de los fuertes, de los que, frente a las negruras de una realidad triste, cobran nuevos alientos y siguen peleando para vencer al Destino en lo porvenir.

Por eso el autor de Malgré tout, perdido su brazo derecho, consagrase durante meses y meses a educar el brazo que le restaba, y logró, por fin, vencer.

Hoy es uno de los grandes artistas de nuestra época y hace honor a Rodin, su inmortal maestro. ${ }^{36}$

También en el mencionado periódico oficial del estado de Aguascalientes, continúan los elogios para el "artista trágico", iniciándose así el proceso mitificador del escultor finisecular:

El jurado internacional de Bellas Artes al otorgar medalla de honor a Jesús Contreras, ha hecho justicia al mérito y ha satisfecho a la opinión competente en materias artísticas.

Nadie dudaba que Contreras obtendría por su estatua Malgré tout la primera recompensa.

Es esta obra admirable, un símbolo arrancado al mármol por el cincel de un artista genial.

Jesús Contreras, enamorado del movimiento y de la vida, posee un espíritu valeroso para la lucha y una fuerza creadora, sólo reservada a las inteligencias privilegiadas; por esto sus obras tienen el sello personal y se apartan de la escuela lamida y de fácil y azucarada belleza que caracteriza a la escuela italiana.

Malgré tout representa a una mujer encadenada, que, no pudiendo andar se arrastra y camina a pesar de todo.

de donde fue tomada para reproducirse tal cual en El Republicano, de Aguascalientes, el 16 de septiembre de 1900 , p. 2.

${ }^{36}$ Jesús F. Contreras, la más alta recompensa artística. El Republicano, 16 de septiembre de 1900, Aguascalientes, p. 2. 
Tal símbolo parece entrañar la voluntad de Contreras que, como su estatua, herido por la desgracia, vióse un día falto de la mano que secundaba en la materia la fuerza de la inteligencia creadora, y supo luchar y vencer, y consiguió salir adelante. ${ }^{37}$

Fue así que para la Exposición Universal de París de 1900, la mayoría de los mexicanos que participaron fueron artistas de la llamada generación modernista; presentaron trabajos de carácter subjetivo, con asuntos cercanos al simbolismo. ${ }^{38}$ Contreras era para entonces un artista consagrado, siendo galardonada su obra Malgré tout, ejecutada en un estilo más avanzado, de contornos difusos y superficies irregulares, pauta que había dictado precisamente el escultor francés August Rodin, quien por cierto fue miembro del jurado que premió la pieza tallada en mármol de Carrara.$^{39}$ Como lo publicó en París Les Temps, junto a "Chucho", como lo llamaban sus amigos, obtuvieron el gran premio de escultura y grabado en medallas artistas de distintas nacionalidades. ${ }^{40}$

En esa última época parisina, Contreras cumplió con varios papeles de representación oficial en nombre del gobierno mexicano, y se relacionó

${ }^{37}$ Jesús F. Contreras, la más alta recompensa artística. El Republicano, 16 de septiembre de 1900, Aguascalientes, p. 2.

${ }^{38}$ Entre los escultores se hallaban además de Jesús F. Contreras, Fidencio Nava, Agustín Ocampo y Guillermo Cárdenas; entre los pintores, Leandro Izaguirre, Gerardo Murillo, Alberto Fuster -este de una generación anterior-; entre los arquitectos Antonio de Anza, Emilio Dondé, Guillermo Heredia, quienes también eran de la generación anterior. Véase Ramírez (1983, pp. 138-139).

${ }^{39}$ La mención a Rodin y el galardón para Jesús Contreras puede localizarse en el Journal Officiel de la République Française, del 19 de agosto de 1900, p. 36. Recuperado de la BnF en http://gallica.bnf.fr/ark:/12148/bpt6k62495484/f52.image.r=jesus\%20contreras\%20\%20\%20 le\%20gaulois?rk=107296;4

${ }^{40}$ Franceses Jean-Paul Aubé, Ernest Barrias, Frédéric Bartholomé, Alfred Boucher, Jules Chaplain, Antonin Carlès, Alexandre Charpentier, Félix Charpentier, Jules Coutan, Emmanuel Fremiet, Georges Gardet, Georges Lemaire, L.-H- Marqueste y Gustave Michel. Asimismo, los rusos Mark Antokolsky y P. Trubetzkoï; los italianos Ernest Bazzaro, Vincent Gemito y Ernest Biondi; los alemanes Reinhold Begas, Cipris Breuer y Robert Diez; el español M. Blay y Fabrega; el holandés Mlle W.-M. Bosch Reitz; los belgas I. van Briesbracke, J. Lambeaux y Julian Dillens; los británicos Thomas Brock, George Frampton y H. Thornycrof; el suizo Antonio Chiattone; los húngaros Jean Farusz, Georges Zala y Aloyse Strobl; los estadunidenses Daniel French y F. Mac Monnies; el portugués Antonio-Teixeira Lopes; así como el austriaco Anton Scharff.Dernieres nouvelles. Les recompenses de l'Exposition. Les Temps, 17 de agosto de 1900, p. 4. Recuperado de la BnF http://gallica.bnf.fr/ark:/12148/ bpt6k236482h/f4.image.r=\%22jesus\%20contreras\%22 
con diplomáticos y artistas de Francia y de diversas partes del mundo. Presuponemos que hacía uso de su influencia en la esfera política, pues por la prensa parisina nos enteramos de que su cuñado, Emilio Elizondo, era parte del Comisariado Mexicano para la Exposición Universal, como puede leerse en el relato de una de las cenas ofrecidas en el pabellón de la república (véase imagen 10). La crónica aparecida en La Justice, destaca la presencia de un grupo selecto de invitados de diversas latitudes, así como la esposa del escultor, Carmen Elizondo, quienes pudieron degustar de una elegante cena acompañada con las notas de dos orquestas. ${ }^{41}$

En diciembre de 1900 regresó a la ciudad de México. Al parecer no volvió a pisar tierra aguascalentense. Él no lo sabía, pero le quedaba año y medio de vida. Lo cierto es que en ese lapso "Volvió a la patria, ebrio de actividad, rico en proyectos progresistas que empezó a poner en planta. Nombrado inspector de bellas artes, daba comienzo, en bien de su país, a un plan general, cuando la afección cancerosa localizándose en la médula espinal", se manifestó con síntomas mortales. ${ }^{42}$

\section{NARRACIONES SOBRE SU MUERTE Y LEGADO}

Luis González (2002) llama a la modernista "generación azul", aquella que le tocó nacer en lo más cruento de las guerras de Reforma, intervención y República Restaurada; nacidos y criados en el ámbito urbano, de familias "decentes", cultos, librescos, formados en prestigiados institutos mexicanos, estadunidenses o europeos, de cultura marcadamente afrancesada, que frecuentaron "burdeles, bares y consumieron a lo bestia alcohol, drogas y hembras"; muchos de ellos se destacaron por su "amor a la lectura de autores ocultistas", "amenazas del zodiaco" y la masonería (pp. 81-82). En efecto, tal perfil encaja, en parte, con la trayectoria del joven Jesús F. Contreras.

El escultor "le daba rienda suelta a la hilacha" y se divertía a lo grande. Tenía amigos entrañables. Uno de los más cercanos y cómplice en sus parrandas y desenfrenadas correrías en prostíbulos, fue el prestigiado escritor

${ }^{41}$ Les fêtes au pavillon du Mexique. Le Justice, 10 de julio de 1900, p. 1. Recuperado de la BnF en http://gallica.bnf.fr/ark:/12148/bpt6k825585p/f1.image.r=\%22emilio\%20elizon do\%22? rk $=21459 ; 2$

${ }^{42}$ Muerte del escultor Jesús F. Contreras. El Imparcial, 13 de julio de 1902, México, D.F., p. 2 [HNDM]. 


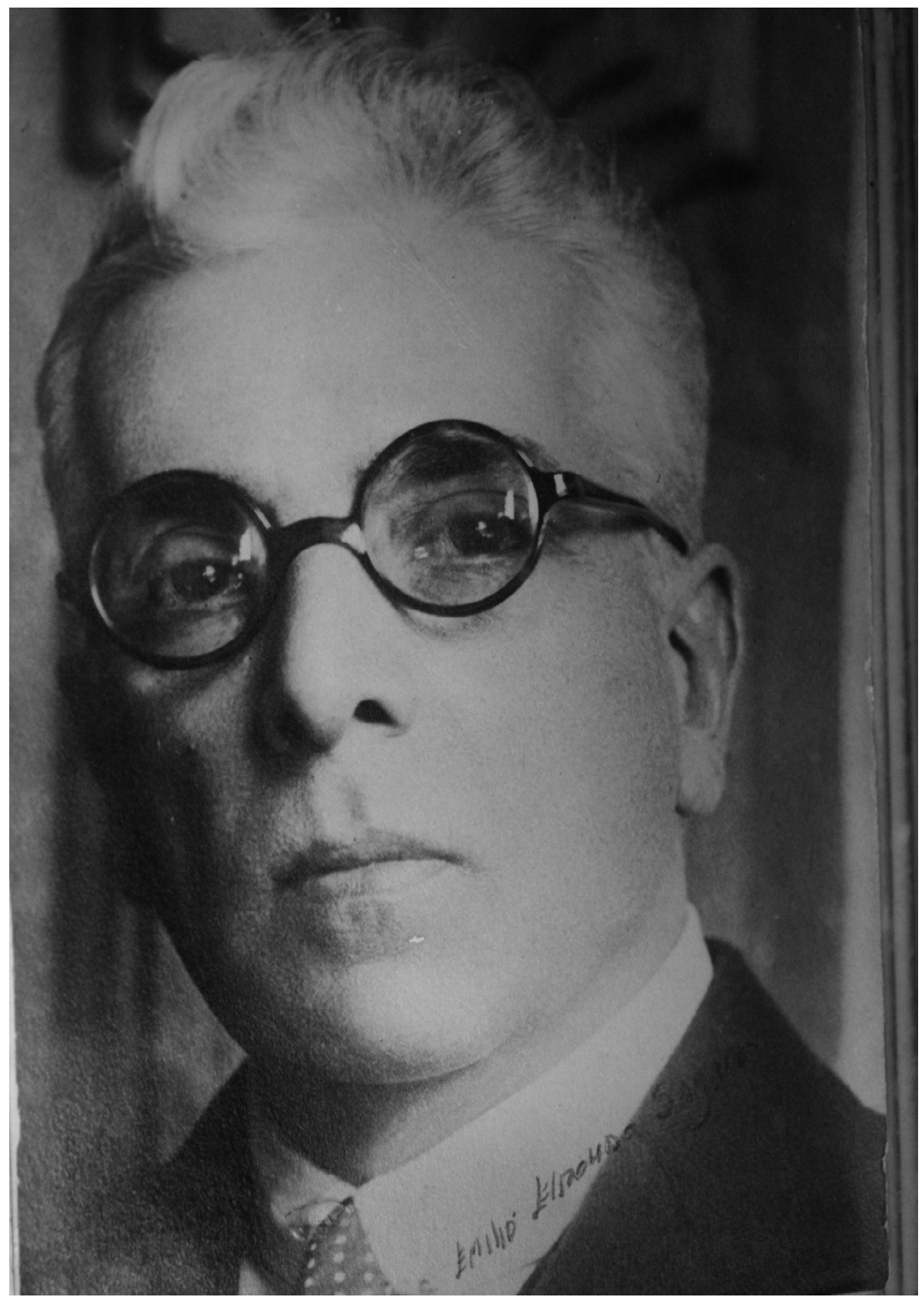

Imagen 10. Emilio Elizondo Sagredo, cuñado de Jesús F. Contreras. Archivo Carlos Contreras de Oteyza. Álbum fotográfico de la familia Contreras. 
Federico Gamboa -autor, entre otras obras, de Santa-; con él vivió una serie de momentos tempestuosos, de arrebatos pasionales. Vida, muerte y lujuria fueron sus temas de conversación -en casas de citas, en charlas de café, en el taller de Contreras-, además del arte y la literatura, en que inevitablemente estaban implicadas sus fascinaciones, esto es, sus mujeres (Prior, 2016, pp. 216-229). ${ }^{43}$ Por otro lado, Vincent (1989) señala que en aquella época "al hombre casado, frecuentador de los burdeles se le tenía como normal” (p. 352).

"México pierde con Jesús F. Contreras, uno de sus más distinguidos artistas", comienza la nota de El Imparcial. Tras su fallecimiento, doloroso suceso que sacudió a la sociedad mexicana acaecido la madrugada del 13 de julio de 1902, el diario se apresuró a recapitular, hacer su semblanza y trayectoria, un tanto idealizada -que continuaba, por tanto, el proceso mitificador del personaje, iniciado desde la amputación de su brazo un año antes-, pues habló de la sólida formación que recibió en México al lado de su maestro Noreña, misma que prosiguió en París donde se distinguió "en los talleres más conocidos", vivió "la vida del arte y del estudio, con artistas que hoy son celebridades"; regresó a México con fervientes deseos de trabajar, "incansable, inspirado y emprendedor, al frente de la fundición artística nacional”, donde llevó a cabo con creatividad desbordante cuanto su imaginación pudo "convertir en obra plástica". ${ }^{4}$

Por cierto que en esos años radicaba en la metrópoli Juan B. Chávez, primo de Contreras, su colaborador y hombre de confianza quien "supo distinguirse como honrado e inteligente artesano en la Fundición Artísti$\mathrm{ca}$, donde mutuamente se ayudaban en los trabajos más arduos y delicados de aquella importante empresa, de donde han salido multitud de obras de mérito". 45

Otro medio que dio a conocer algunos detalles de su lento padecer, de cómo fue perdiendo paulatinamente su motricidad y demás facultades, de la atmósfera fúnebre que se apoderó de la casa familiar, de la actitud de su cónyuge, de su último aliento, fue El Imparcial; se narra con dramatismo:

${ }^{43}$ El autor conjetura -fundamentalmente a partir del diario íntimo del primero- que tanto la novela Santa como la escultura Malgré tout, fueron obras muy probablemente inspiradas por las amantes que ambos llegaron a tener.

${ }_{44}$ Muerte del escultor Jesús F. Contreras. El Imparcial, 13 de julio de 1902, México, D.F., p. 2 [HNDM].

${ }^{45}$ Gacetilla. Necrología. El Republicano, 13 de noviembre de 1904, Aguascalientes, p. 7. Juan B. Chávez falleció en la ciudad de México el 4 de noviembre de 1904. 
Hace tres meses se anunciaron los primeros síntomas de la parálisis; tres meses de agonía; tres meses de muerte lenta que los recursos de la ciencia fueron impotentes para contenerla. El sábado [12 de julio de 1902] en la mañana, la parálisis invadió las cuerdas vocales y los músculos respiratorios, el artista enmudeció para siempre. Durante el día su estado fue agravándose: el pronóstico de los médicos era fatalmente mortal, y desde ese momento, la casa del artista, alegre, amueblada y decorada con talento, rica en obras de arte; la casita embellecida por una esposa admirable en su cariño, en su abnegación cristiana; en su heroica entereza; se tornó ayer en algo silencioso y siniestro como un gran nido velado por crespones.

Cerca de la medianoche el desenlace se esperaba por instantes; el enfermo estaba sumido en el coma artificial de la morfina, y cerca de él un gran número de amigos conmovidos, esperaba todavía un milagro... A las doce y veinticinco minutos, expiró Jesús F. Contreras. ${ }^{46}$

La casa de la familia Contreras Elizondo se ubicaba en la calle de Fuentes Brotantes (hoy Lucerna). Lo acompañaron en las piezas contiguas a su lecho de muerte, en su último aliento, "atentos a las peripecias de la catástrofe", el escultor Juan Fernández, su paisano y pariente el maestro Ezequiel A. Chávez, el poeta Luis G. Urbina, el también artista y escultor catalán Federico Homdedeu, ${ }^{47}$ el notario Jesús Trillo "y otros muchos".

En la madrugada del domingo y sobre todo durante buena parte del día 13, "incontable número de personas visitaron la casa mortuoria: profesores, artistas, amigos, favorecidos, dando lugar a escenas tistes; pero evidenciando las grandes simpatías y el gran cariño de que fue objeto siempre". Enviaron montones de flores tanto individuos como instituciones, desde la Presidencia de la República hasta la Escuela Nacional Preparatoria, pasando por la Escuela Nacional de Bellas Artes y la Subsecretaría de Instrucción Pública, según prosigue el relato de El Imparcial. ${ }^{48}$

${ }^{46}$ Muerte del escultor Jesús F. Contreras. El Imparcial, 13 de julio de 1902, México, D.F., p. 2 [HNDM].

${ }^{47}$ No está del todo claro cómo, cuándo y por qué llegó a México Federico Homdedeu, lo cierto es que estuvo en la Fundición Artística Mexicana, se encargó de ella cuando Contreras se fue a Europa en 1898, y allí se fundieron varias esculturas de su autoría (de personajes de Tamaulipas y Oaxaca) que fueron colocadas en la última etapa en el Paseo de la Reforma; murió en 1898. Véase Pérez Walters (2016b, pp. 159, 177, 185, 210, 215, 287, 290, 389).

${ }^{48}$ Muerte del escultor Jesús F. Contreras. El Imparcial, México, D.F., 14 de julio de 1902, p. 2 [HNDM]. 
Carmelita Elizondo sabía de la fama, prestigio y estimación que su marido gozaba en el mundo del arte, la cultura, la literatura y hasta de la elite política, razón por la cual solicitó a los amigos de Contreras hicieran un par de trabajos artísticos, valiéndose de su cuerpo yaciente; dice la crónica: "A ruego de la distinguida y desventurada viuda, se modeló la mano del cadáver. El señor Rosas, de la Academia, tomó un boceto al óleo, del busto, y otro a lápiz Don José M. Villasana. ${ }^{349}$ ¿Era consciente que se gestaba un proceso mitificador y alguien se lo sugirió o simplemente consideró que era un oportuno y justo tributo a su difunto esposo? $?^{50}$ (véanse las imágenes 11 y 12).

El general Porfirio Díaz -amigo personal y socio del escultor, ya que fue el presidente del Consejo de la Fundición Artística Mexicana y Contreras fungió como director técnico-, quien "tuvo gran afecto por el ilustre finado", desde su investidura de primer mandatario de la nación, "vivamente conmovido" y tan luego como "recibió la triste nueva, dio las órdenes más amplias y más merecidas para el arreglo de los honores fúnebres" que habrían de tributarse al artista. Justo Sierra Méndez -también amigo y además compadre de Contreras-, ${ }^{51}$ "dispuso que el cadáver fuese trasladado, después de la inyección, al salón de actos de la Escuela de Bellas Artes, convertido en capilla Ardiente". Esto ocurrió al anochecer.

Ninguna crónica respecto a su muerte, velorio, honras fúnebres y sepelio menciona nada relacionado con los ritos de la religión católica, a pesar de que Contreras había sido formado en ella. ¿Así lo dispuso Jesús F. Contreras, expresamente, cuando estaba lúcido y sabía que su fin estaba próximo?, ¿encierra algún rito o práctica masónica la disposición, ornato y arreglos en la ENBA? Así la describe el periodista del diario de mayor circulación en el país:

49 El dibujo del natural realizado por Villasana, fue publicado en El Mundo Ilustrado, también de Rafael Reyes Spíndola, el 20 de julio de 1902; véase Pérez Walters (2002, p. 178).

50 Tanto la máscara mortuoria como la mano modelada en yeso se conservan en el Museo de Aguascalientes. Fueron exhibidas por primera vez en 2016, durante el sesquicentenario del nacimiento del escultor.

${ }^{51}$ Justo Sierra fue padrino de bautizo de su hijo Rubén Julián, en 1895, tres años después de la fundación del Ateneo Literario y Artístico Mexicano; véase Bóveda Jesús F. Contreras, Archivo Particular Jesús F. Contreras, Sección documental, Doc. 000029, f. 1. Castillo Sosa (2013, p. 21), da cuenta de las relaciones de compadrazgo, la estrecha relación de amistad y cariño, así como la frecuente correspondencia epistolar entre ambos. 


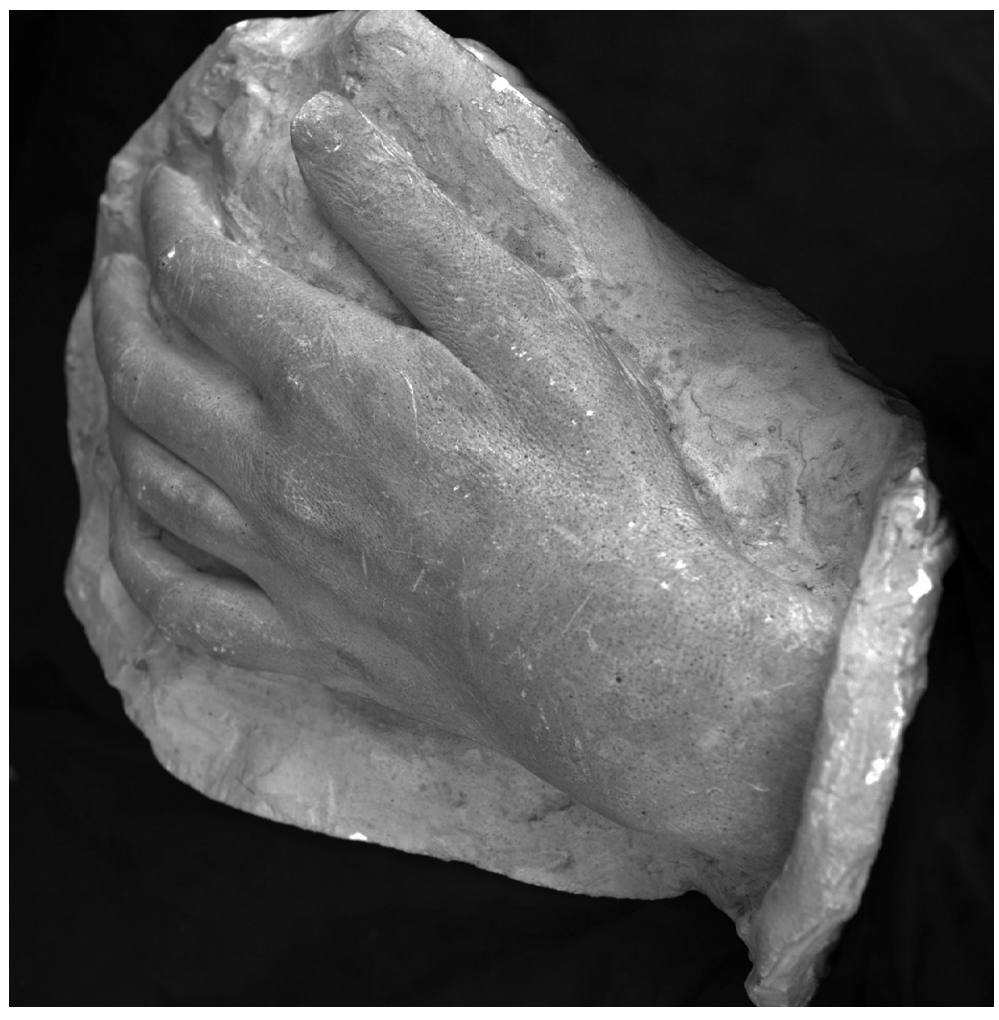

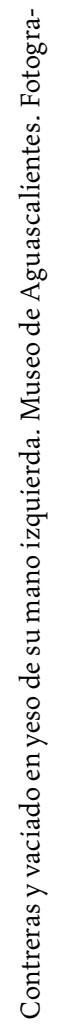

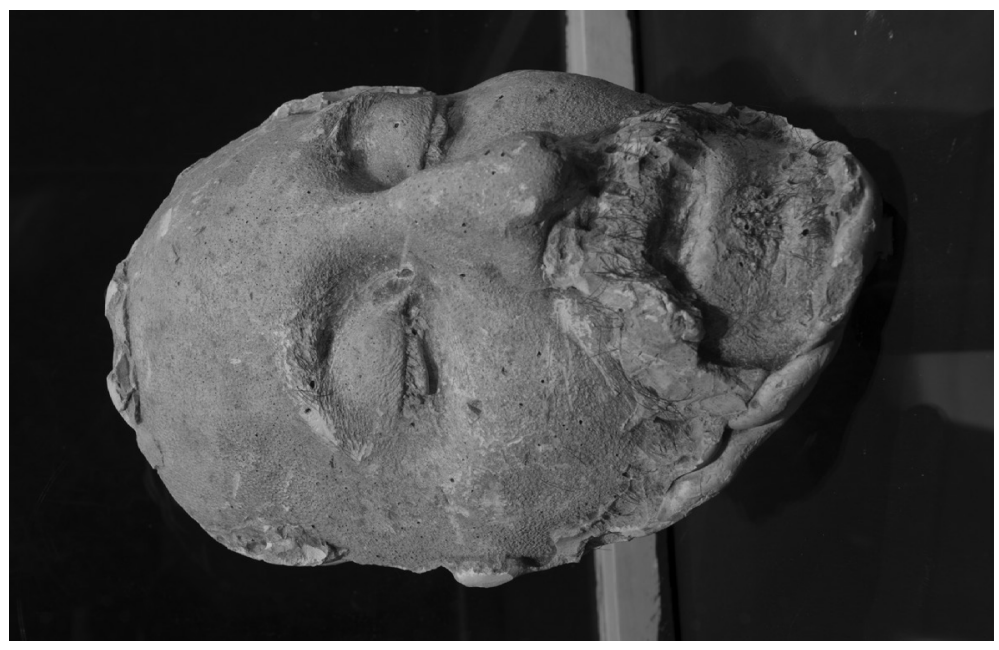

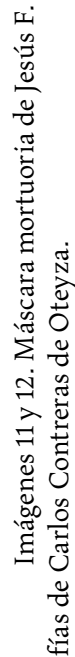


La capilla ardiente erigida en la Escuela de Bellas Artes estaba formada por una escalinata forrada de paño negro y atestada de coronas, en medio de la cual, el féretro yacía a lo largo, descansando en medio de una gran corona. A uno y otro lado había pequeñas lámparas verdes, y al pie de ellas, a los lados de la escalinata, sobre las gradas, en torno al féretro, sobre él, multitud de coronas. Toda la Escuela estaba enlutada: las puertas, los corredores, los arcos, el patio, y en el fondo de este último el monumento de Acuña, ejecutado por Contreras, envuelto en crespones. ${ }^{52}$

De inmediato se hicieron las guardias de honor, formando el primer turno precisamente el subsecretario de Instrucción Pública y don Román S. de Lascuráin; durante toda la noche, madrugada del lunes, continuaron las guardias ante el féretro, entre los que se pudo ver además de los antes dichos personajes, a sus entrañables colegas y empleados de la Fundición Artística Mexicana; amigos y contertulios del Ateneo Mexicano Literario y Artístico, varios de ellos reconocidos poetas y escritores; de sus maestros, condiscípulos y alumnos de la Escuela Nacional de Bellas Artes, artistas consumados o en ciernes:

doctor Manuel Flores [...] Guillermo Cárdenas, Agustín Ocampo, Manuel Sierra, Carlos Solórzano, Carlos Meneses, Gustavo E. Campa, Luis Urbina, Juan de Dios Fernández, Federico Homdedeu, Manuel y Enrique Torres Torija, Manuel Riva y Río, Ramón S.N. de Araluce, José Juan Tablada, Luis Quintanilla, Germán Gedovius, Julio Ruelas, José María Villasana, César del Castillo, Jesús Trillo, Jesús E. Valenzuela, Ángel del Campo, Monacal el arquitecto, Manuel Galindo y Villa. ${ }^{53}$

El cortejo fúnebre partió en punto de las nueve y media de la mañana del lunes 14 de julio. La carroza en que viajó el féretro era de "gran gala", seguida de numerosos carros que "iban completamente llenos de personas amigos del artista”. Una hora más tarde llegó la comitiva al Panteón Francés, en La Piedad; varios mozos "trasladaron el féretro hasta la fosa, y apenas

${ }^{52}$ Muerte del escultor Jesús F. Contreras. El Imparcial, México, D.F., 14 de julio de 1902, p. 2 [HNDM].

${ }_{53}$ Muerte del escultor Jesús F. Contreras. El Imparcial, México, D.F., 14 de julio de 1902, p. 2 [HNDM]. 
puesto en tierra, en medio del grupo de personas que lo rodeaban avanzó el poeta Amado Nervo", quien visiblemente conmovido en su alocución -entre otras cosas- dijo: "Y ahora, artista, hermano: hasta luego." ${ }^{54}$

No podían faltar al sepelio sus paisanos, "Lic. Ezequiel Chávez, ${ }^{55}$ Doctor Jesús Díaz de León, Samuel Chávez, José Herrán ${ }^{56}$ David Chávez y José F. Elizondo" ${ }^{57}$ La colonia de Aguascalientes en la ciudad de México estaba representada por estos intelectuales, entre los que figuraban educadores, periodistas eruditos, inventores cultos, políticos y dramaturgos. Seguramente no pudo acudir su tío político, Carlos Sagredo García Rojas, por estar al frente de la gubernatura del estado de Aguascalientes y no poderse desprender de sus tareas.

La prensa de circulación nacional mencionó la patria chica de Contreras y reconoció su generosidad para con sus coterráneos, pues siempre estuvo dispuesto a ayudarles: "El artista nació en la hermosa capital del Estado de

${ }^{54}$ Muerte del escultor Jesús F. Contreras. El Imparcial, México, D.F., 14 de julio de 1902, p. 2 [HNDM]. Tanto Amado Nervo como Juan de Dios Peza, quienes le dedicaron poemas conmemorativos a Contreras, tuvieron cargos en las logias mexicanas (así como Federico Gamboa), por lo que el uso de la palabra "hermano" por el primero, nos lleva a pensar en la posibilidad de que el ilustre escultor fallecido hubiese pertenecido a la masonería.

${ }^{55}$ Como vimos, los Chávez eran sus parientes, por ejemplo, Ezequiel Adeodato Chávez Lavista (1868-1946), intelectual, educador y político, era su sobrino (Anaya Merchant, 2002). Por otro lado, Martínez y Esparza (2016, p. 35) señalan: "A lo largo de los años, Jesús coincidió con muchos miembros de su familia en la ciudad de México o en París, y tuvieron caminos y vivencias paralelas"; además han descubierto la amplia red de amigos y familiares de los Contreras con los Elizondo, desde luego, pero también con los Sagredo, los Chávez, los Pani y otras posibles relaciones parentales con los Arteaga, López de Nava, Vázquez del Mercado, importantes en los periodos de la República Restaurada y el porfiriato, algunos de cuyos integrantes descollaron en la revolución mexicana y aún después. Cfr. Velázquez Chávez (1983).

${ }^{56}$ José Herrán fue un dramaturgo, político e inventor, "instruido, estudioso y de un talento nada común"; fue muchos años tesorero general del gobierno del estado de Aguascalientes, diputado en la legislatura local, un tiempo colaboró como redactor del periódico El Instructor; lo sorprendió la muerte cuando se desempeñaba como diputado suplente al Congreso de la Unión, el 19 de enero de 1903; fue el padre del pintor aguascalentense Saturnino Herrán. R. Espinosa, Necrología, El Republicano, 25 de enero de 1903, p. 11.

${ }^{57}$ José F. Elizondo (1880-1943) era su cuñado -hermano de su esposa Carmen-, y que se convertiría en ilustre dramaturgo, poeta, epigrafista, director de revistas, periodista cultural, crítico, cronista y actor. También puede verse en el archivo particular de José F. Elizondo, resguardado en la Bóveda Jesús F. Contreras de la Universidad Autónoma de Aguascalientes, varias fotografías de la familia política del escultor: de José F. Elizondo, desde luego (adolescente, joven, ya maduro), de su suegra Josefa Sagredo García Rojas, de sus otros dos cuñados Emilio José Ignacio y Tibaldo Primitivo, de su esposa Carmen y sus cuñadas Felicia, Teresa y Aurelia (Ramírez, 2016a, pp. 110-113). 
Aguascalientes, la colonia de aquella Entidad fue la que más sintió su partida eterna, porque era uno de sus miembros prominentes y porque siempre estuvo dispuesto el escultor a proteger y a ayudar a todos los que de aquel Estado venían a esta capital. ${ }^{n 8}$

Jesús F. Contreras fue una persona que se daba a querer, y por eso tenía entrañables amigos. Por otro lado, de unos años a la fecha estuvo muy cercano a las altas esferas del poder político y próximo a las elites sociales, culturales y artísticas. Por eso recibió honras fúnebres, casi como de estadista.

El Tiempo, Diario Católico, dirigido por su fundador y propietario Victoriano Agüeros, señaló que "El señor Contreras, como es sabido, es el autor de la preciosa escultura 'Malgré tout', y al sorprenderlo la muerte, tenía en proyecto importantísimas reformas que pensaba introducir en la Academia", además de que "había salido electo diputado por el noveno distrito de San Luis Potosí". Advirtió, por otro lado, que al sepelio acudieron "cerca de 300 personas", daba el "sentido pésame" a los deudos y remató categórico el periódico: "Su fallecimiento ha sido, y con justicia, extraordinariamente sentido en la sociedad mexicana". 59

Con una semana de retraso la opinión pública de Aguascalientes se enteró de que uno de sus hijos predilectos había fallecido. Después de halagar la destacada trayectoria del "inteligente escultor", una nota publicada en primera plana del periódico oficial hizo notar que fue el ejecutor de "celebradas obras de arte", muchas de ellas de "esclarecidos patriotas" que lucen en la avenida del Paseo de la Reforma, entre las que destacan las "hermosas estatuas" de los aguascalentenses Francisco Primo de Verdad y José María Chávez costeadas por el gobierno del estado. Se hace notar que la fatal noticia causó consternación y tristeza en amplios sectores de la sociedad capitalina, donde además "Contreras disfrutaba de generales simpatías entre sus paisanos". Se despide diciendo: "En México y en esta ciudad [de Aguascalientes], residen miembros de la atribulada familia del finado. A unos y a otros, les enviamos los sinceros sentimientos de nuestra condolencia", concluían los editores de El Republicano. ${ }^{60}$

\footnotetext{
${ }^{58}$ Muerte del escultor Jesús F. Contreras. El Imparcial, México, D. F., 14 de julio de 1902, p. 2 [HNDM].

${ }_{59}$ Muerte del Sr. Jesús F. Contreras. El Tiempo. Diario Católico, México, D.F., 15 de julio de 1902 , p. 3 [HNDM].

${ }^{60}$ Lamentable defunción. El Republicano, Aguascalientes, 20 de julio de 1902, p. 1.
} 


\section{CONCLUSIÓN}

Para Fausto Ramírez (1983, p. 139), la política artística y cultural del porfiriato, osciló entre dos polos, según conviniera a sus intereses: "uno, acentuadamente nacionalista y apoyado en la exaltación de valores históricos específicos; otro, voluntariamente cosmopolita y moderno". El escultor Jesús F. Contreras, fallecido en plenitud de su vida, a no dudarlo, es uno de sus más destacados exponentes, sin olvidar que algunas bases las adquirió en su ciudad natal. ${ }^{61}$

Por tratarse de un personaje de talla internacional, sus coetáneos y paisanos le rindieron homenajes póstumos el mismo año de su fallecimiento y dos años después en Aguascalientes: José Juan Tablada, Amado Nervo, Juan de Dios Peza, Federico Gamboa, Luis Villa y Gordoa, José F. Elizondo, entre otros. Como dice Patricia Pérez Walters (2016b, pp. 372-378), empezó a recibir trato de héroe cultural, en tanto figura arquetípica de artista moderno, revestida de un aura trágica.

Tal fue la influencia de Contreras en sus coetáneos, que es posible apreciarla en la línea estética de escultores como Fidencio L. Nava, Arnulfo Domínguez Bello y otros. Se puede medir incluso con las falsas atribuciones de obras, como el caso de Désespoir, de su alumno Agustín Ocampo, por la errata del historiador Justino Fernández (1971, p. 82) y por el gran parecido estilístico con Malgré tout; las constantes alusiones a monumentos en honor a Benito Juárez en Chihuahua y Oaxaca -en realidad de manos extranjeras-, o bien la atribución errónea, sobre la hechura del águila republicana cuya réplica despliega sus alas en lo alto de la gran columna jónica en la exedra de la plaza principal de Aguascalientes, falsamente atribuida a Contreras, versión que hasta la fecha se divulga públicamente.

Este último caso es curioso, pues el verdadero autor, Georges Gardet, también obtuvo un Gran Prix de escultura en la Exposición Universal de 1900, como Jesús Contreras, y al igual que el mexicano, recibió la condecoración como Caballero de la Legión de Honor de la República Francesa, según

${ }^{61}$ En 1904 Jesús F. Contreras fue objeto de un homenaje, In Memoriam, organizado por su cuñado José F. Elizondo (Pepe Nava) en su natal Aguascalientes. En ese año Baudelio Contreras, hermano del finado, hizo dos viajes a Aguascalientes, en febrero y diciembre, R. A. Espinosa. Gacetilla. Bienvenida. El Republicano, 31 de febrero de 1904, p. 7; R. A. Espinosa. Gacetilla. Ilustre viajero. El Republicano, 25 de diciembre de 1904, p. 7. 
información del Museo del Prado. ${ }^{62}$ La cuestión estriba en que la pieza de cobre martillado fue pensada para coronar el Palacio Legislativo porfiriano que nunca fue concluido, pero que en 1940 se destinó para la cima del conjunto escultórico conocido como el Monumento a la Raza, en la ciudad de México, para el que también se reciclaron cuatro relieves que el aguascalentense realizó para el "Palacio Azteca" en la Exposición Universal de 1889; quizás por ello, la asociación e incorrecta atribución. Por cierto, las fotografías de la manufactura de la citada ave del escudo nacional pueden consultarse en el acervo del Museo D'Orsay. ${ }^{63}$

Como apunta el historiador del arte español José Fernández Arenas (1990): "En la transmisión de los datos biográficos se mezclan muchas veces anotaciones novelescas, fantasías inventadas por la imaginación popular o acontecimientos despertados por la resonancia de las obras, datos en algunos casos útiles, pero claramente perturbadores en otros" (p. 55).

Cuando la principal biógrafa de Jesús F. Contreras terminó de escribir su tesis de licenciatura en Historia del Arte, en 1989, hizo notar que el legado dejado por el escultor mexicano era enorme, que se requería una nueva postura del historiador y que precisaba una cabal comprensión totalizadora de su personalidad, quehacer artístico y trayectoria profesional. Queda mucho por investigar respecto a la figura del estudiante, lo mismo que del artista empresario, esto es, en torno a la Fundición Artística Mexicana, el Taller de Alfarería Artística; falta profundizar, asimismo, en su papel como "eje del grupo modernista", de sus propuestas para reformar en la enseñanza artística, y por supuesto en la posible influencia estilística sobre otros escultores (Pérez Walters, 1989, pp. 235-236, 272, notas 521 y 523).

Merece la pena seguir abundando en una "personalidad artística tan rica y una producción tan vasta y significativa", como es el caso de Jesús $\mathrm{F}$. Contreras y su obra, artista aguascalentense en el que "está esculpido, en cuerpo y alma, el México finisecular" (Pérez Walters, 1989, p. 237). Desde luego, el tema no está agotado y seguiremos esperando nuevas aportaciones y acercamientos de los especialistas en el ramo.

${ }^{62}$ Gardet, Georges. En Enciclopedia del Museo del Prado. Museo del Prado. Recuperado de https://www.museodelprado.es/aprende/enciclopedia/voz/gardet-georges/8d22d088 $-492 b-4 f d 1-b 17 e-6 e 09 f 4909160$

${ }^{63}$ L'aigle de Mexico (ca. 1912). Catalogue des œuvres. Museo D’Orsay. Recuperado de http://www.musee-orsay.fr/fr/collections/catalogue-des-oeuvres/notice.html?no_cache $=1 \&$ nnumid $=078765 \&$ cHash $=b 1 \mathrm{bcc} 5 \mathrm{~b} 574$ 


\section{LISTA DE REFERENCIAS}

Anaya Merchant, L. (2002). Ezequiel A. Chávez. Una aproximación biográfica a la historiografía de la rectificación. Aguascalientes: Instituto Cultural de Aguascalientes/ CIEMA.

Castillo Sosa, E. H. (2013). Jesús F. Contreras, el escultor del régimen. (Tesis de licenciatura inédita). Universidad Autónoma de Aguascalientes, México.

Delgado A., F. J. (2007). Historia del Congreso del Estado de Aguascalientes (1835-1950). Aguascalientes: Gobierno del Estado/Instituto de Investigaciones Legislativas.

Díaz de León, J. (1891). La exposición de Bellas Artes en Aguascalientes. México: José J. López.

Encino, A. G., y Gómez, M. G., (2016). Convergencias: análisis del legado de Jesús F. Contreras desde la perspectiva del diseño. En L. Ramírez y A. G. Rodríguez Sánchez (coords.), Jesús F. Contreras. Pasión y poder escultórico (pp. 96-109). Aguascalientes: Instituto Cultural de Aguascalientes/Universidad Autónoma de Aguascalientes/Secretaría de Cultura.

Engel, J. L. (1997). Diccionario general de Aguascalientes. Aguascalientes: Instituto Cultural de Aguascalientes.

Fernández, J. (1971). El siglo romántico. El arte de México en el siglo xix. En X. Moyssén, Cuarenta siglos de plástica mexicana. Arte moderno y contemporáneo (pp. 25-89). México: Herrero.

Fernández, J. (2001). Arte moderno y contemporáneo de México. El arte del siglo XIX. T. I. México: Universidad Nacional Autónoma de México-Instituto de Investigaciones Estéticas.

Fernández A., J. (1990). Teoría y metodología de la historia del arte. Barcelona: Antropos. Fernández M., F. J. (2006). Los denuedos de Jesús Díaz de León y su proyecto de El Instructor. Boletín del Archivo Histórico del Estado de Aguascalientes, 2, 25-39.

García Robles, M. A. (2016a). A la sombra de la Torre Eiffel. Los relieves de Jesús F. Contreras para el Pabellón Mexicano en la Exposición Universal de París de 1889. Aguascalientes: Universidad Autónoma de Aguascalientes.

García Robles, M. A. (2016b). Los bronces franco-mexicas de Jesús F. Contreras: manifiesto porfirista de 1889. En L. Ramírez y A. G. Rodríguez Sánchez (coords.), Jesús F. Contreras. Pasión y poder escultórico (pp. 198-215). Aguascalientes: Instituto Cultural de Aguascalientes/Universidad Autónoma de Aguascalientes/Secretaría de Cultura.

Gómez, J. (2006). Notas sobre el diletantismo científico y cultural de Jesús Díaz de León. Boletín del Archivo Histórico del Estado de Aguascalientes, 2, 9-23. 
González, L. (2002). El cardenismo. Los artífices del cardenismo. En Obras (t. 4, pp. 3-223). México: El Colegio Nacional.

Luévano, A. (13 de junio de 2016). La Colmena. Una pensión para Jesús F. Contreras. Página 24, p. 7. Recuperado de http://pagina24.com.mx/columnas/2016/06/13/ colmena-68/

Martínez Assad, C. (2005). La Patria en el Paseo de la Reforma. México: Fondo de Cultura Económica/Universidad Nacional Autónoma de México.

Martínez Delgado, G. y Esparza, V. (2016). El sello artesanal. Familia y ciudad en los primeros años de Jesús F. Contreras Chávez. En L. Ramírez y A. G. Rodríguez Sánchez (coords.), Jesús F. Contreras. Pasión y poder escultórico (pp. 16-36). Aguascalientes: Instituto Cultural de Aguascalientes/Universidad Autónoma de Aguascalientes/Secretaría de Cultura.

Moyssén, X. (2011). José María Velasco. Un estudio sobre su obra. En C. Camacho Quiroz (coord.), José María Velasco (pp. 7-22). Toluca: Gobierno del Estado de México/Secretaría de Educación.

Pérez Walters, P. (1989). Jesús Fructuoso Contreras (1866-1902). Imágenes escultóricas y personalidad artística. (Tesis de licenciatura). Universidad Iberoamericana, México.

Pérez Walters, P. (2002). Alma y bronce. Jesús F. Contreras 1866-1902. Aguascalientes; Instituto Cultural de Aguascalientes/Conaculta/Universidad Autónoma de Aguascalientes.

Pérez Walters, P. (2016a). Jesús F. Contreras y la fiebre escultórica del porfiriato. En L. Ramírez y A. G Rodríguez Sánchez (coords.), Jesús F. Contreras. Pasión y poder escultórico (pp. 68-83). Aguascalientes: Instituto Cultural de Aguascalientes/Universidad Autónoma de Aguascalientes/Secretaría de Cultura.

Pérez Walters, P. (2016b). Patria, rostro y sueño. Jesús F. Contreras, escultor del porfiriato. Aguascalientes: Universidad Autónoma de Aguascalientes.

Prior, J. (2016). De vidas y tentaciones paralelas. Federico Gamboa y Jesús F. Contreras. En Jesús F. Contreras. Pasión y poder escultórico (pp. 216-229). Aguascalientes: Instituto Cultural de Aguascalientes/Universidad Autónoma de Aguascalientes/ Secretaría de Cultura.

Ramírez, F. (1983). Vertientes nacionalistas en el modernismo. En El nacionalismo y el arte mexicano, 1900-1940. IX Coloquio de Historia del Arte (pp. 111-167). México: Universidad Nacional Autónoma de México/Instituto de Investigaciones Estéticas.

Ramírez, L. (2016a). Archivo fotográfico José F. Elizondo. Parteaguas, 37, 110-113. Recuperado de http://www.aguascalientes.gob.mx/temas/cultura/editorial/pdfrevistas/Parteaguas37.pdf 
Ramírez, L. (2016b). La Academia de Dibujo de Aguascalientes bajo el modelo francés de enseñanza. Los aprendizajes del "método Julien" de Plácido Jiménez hacia 1844-1846, maestro del escultor Jesús F. Contreras. Escena. Revista de las Artes, LXXV(2), 63-79. DoI: https://doi.org/10.15517/es.v75i2.25578

Ramírez, L. y Luévano, A. (2016). Otros aprendizajes del joven Contreras en Aguascalientes: El Esfuerzo y la Escuela de Niños Número 1. En L. Ramírez y A. G. Rodríguez Sánchez (coords.), Jesús F. Contreras. Pasión y poder escultórico (pp. 37-50). Aguascalientes: Instituto Cultural de Aguascalientes/Universidad Autónoma de Aguascalientes/Secretaría de Cultura.

Reséndiz García, R. (2013). Biografía: proceso y nudos teórico-metodológicos. En Ma. L. Tarrés, Observar, escuchar y comprender: sobre la tradición cualitativa en la investigación social. México: Flacso.

Reyes, A. de los (2002). ¿No queda huella ni memoria? (semblanza iconográfica de una familia). México: Universidad Nacional Autónoma de México-Instituto de Investigaciones Estéticas/El Colegio de México.

Rodríguez, M. G. (2013). Jesús F. Contreras en las exposiciones de París, 1889-1900 (Tesis de licenciatura). Universidad Autónoma de Aguascalientes, México.

Sánchez, F. E. (1996). Catálogo de la Escuela Nacional de Bellas Artes. México: Instituto de Investigaciones Estéticas-Universidad Nacional Autónoma de México.

Speckman, E. (2006). De barrios y arrabales: entorno, cultura material y quehacer cotidiano (Ciudad de México, 1890-1910). En P. Gonzalbo Aizpuru (dir. gral.), Historia de la vida cotidiana en México. T. V. A. De los Reyes (coord.), Siglo XX. Campo y ciudad (vol. 1, pp. 17-47). México: Fondo de Cultura Económica/El Colegio de México.

Tenorio Trillo, M. (1998). Artilugio de la nación mexicana. México en las exposiciones universales, 1880-1930. México: Fondo de Cultura Económica.

Terán Fuentes A. (2011). Aparador del progreso. Análisis del discurso político de las exposiciones del siglo XIX de la Feria (Temporada) de San Marcos, 1851-1891. (Tesis de doctorado). Universidad Autónoma de Zacatecas, México.

Terán, A. (2016). Un modelo en yeso en el centro del Salón de Exposiciones: Jesús F. Contreras en la Exposición de Aguascalientes de 1891. En L. Ramírez y A. G. Rodríguez Sánchez (coords.), Jesús F. Contreras. Pasión y poder escultórico (pp. 140-155). Aguascalientes: Instituto Cultural de Aguascalientes/Universidad Autónoma de Aguascalientes/Secretaría de Cultura.

Tibol, R. (1981). Historia general del arte mexicano. Época moderna y contemporánea (t. I). Barcelona: Hermes. 
Tiscareño Uribarrien, M. (2016). Una lira española en Aguascalientes. Blas Elizondo, legado familiar y poético (1856-1891). En A. G. Rodríguez Sánchez (coord.), Imágenes para la posteridad. El acervo fotográfico de José F. Elizondo, 1880-1943 (pp. 8-13). Aguascalientes: Universidad Autónoma de Aguascalientes.

Velázquez Chávez, A. (1983). Don José María Chávez Alonzo. Semblanzas, iconografía y documentos [Selección y notas]. México: Cultura.

Vincent, G. (1989). ¿Una historia del secreto? En P. Ariés y G. Duby (dir.), Historia de la vida privada. La vida privada en el siglo xx (vol. 9, pp. 155-389). Madrid: Taurus.

\section{OTRAS FUENTES}

Archivos

Acco Archivo Carlos Contreras Oteyza. Álbum fotográfico de la familia Contreras.

AhEa Archivo Histórico del Estado de Aguascalientes.

Ahunam Archivo Histórico de la unam, Colección Justo Sierra.

Amoa Archivo de la Mitra del Obispado de Aguascalientes, Sagrario de Aguascalientes, Matrimonios, 1889-1893.

BJFC/APJFC Bóveda Jesús F. Contreras, Archivo Particular Jesús F. Contreras, Sección documental, localizado en la Universidad Autónoma de Aguascalientes.

BJfC/APJfe Bóveda Jesús F. Contreras, Archivo Particular José F. Elizondo, Sección de fotografía, localizado en la Universidad Autónoma de Aguascalientes.

\section{Hemerografía}

El Instructor, Aguascalientes, Ags., 1887.

El Imparcial, México, D. F., 1902.

El Republicano. Periódico Oficial del Gobierno del Estado. Aguascalientes, 1887-1891.

El Tiempo. Diario Católico, México, D. F., 1902.

Journal Officiel de la République Française, París, Francia, 1900.

La Justice, París, Francia, 1900.

Les Temps, París, Francia, 1900. 